\title{
A black, non-troglomorphic amphibian from the karst of Slovenia: Proteus anguinus parkelj n. ssp. (Urodela: Proteidae)
}

\author{
B. Sket ${ }^{1} \&$ J.W. Arntzen ${ }^{2}$ \\ ${ }^{1}$ Department of Biology, Biotechnical Faculty, University of Ljubljana, Večna pot 111, \\ P.O. Box 486/492, 61000 Ljubljana, Slovenia; ${ }^{2}$ Binnen Oranjestraat 10, $1013 \mathrm{JA}$ Amsterdam, \\ The Netherlands
}

Keywords: Urodela, Proteus, taxonomy, morphology, allozyme analysis, ecology, distribution

\begin{abstract}
A morphologically distinct cavernicolous salamander Proteus anguinus from southeastern Slovenia (Bela Krajina) is described as $P$. a . parkelj ssp. n. It differs from $P$. a. anguinus in a dark pigmentation, fully developed eyes, a skull with broader and shorter bones and fewer teeth, a voluminous jaw musculature that gives the head a bulky appearance, a proportionally longer trunk with a higher number of vertebrae, shorter extremities, and a shorter tail. Most of these traits are considered to be plesiomorphic character states. An allozyme analysis over $\mathbf{4 0}$ loci has shown the new dark pigmented taxon to be genetically similar to a white and troglomorphic neighbouring population from Stična $\left(D_{\mathrm{Nei}}=0.23\right)$. Both populations in turn are genetically dissimilar to a geographically more distant population from Postojna $\left(D_{\mathrm{Nei}}=0.49\right)$. The observed level of genetic differentiation suggests that western and southeastern Slovenian populations form separate lineages since the uppermost Miocene but conservatively hitherto only a single species is recognised. The new taxon is only known from a small area and may be rare. $P$. a. parkelj, now under strict legal protection, is threatened by industrial pollution.
\end{abstract}

\section{Résumé}

Un Protée remarquable de Slovénie du sud-est (Bela Krajina) est décrit comme Proteus anguinus parkelj ssp. n. Celui-ci se distingue de la sous-espèce nominative par la pigmentation très foncée, les yeux bien développés, le crâne à os plus courts et élargis, un nombre inférieur de dents, la musculature des mandibules plus fortement développée (ce qui donne à la tête un aspect plus massif), le corps relativement plus allongé et à nombre supérieur de vertèbres, ainsi que par les pattes et la queue plus courtes. La plupart de ces caractères sont considérés comme étant plésiomorphes. L'analyse des allozymes à 40 loci montre que ce taxon à pigmentation foncée ressemble au point de vue génétique $\left(D_{\mathrm{Nei}}=0.23\right)$ à la population troglomorphe dépigmentée d'une localité située à proximité (Stið̌na). Cependant, ces deux popula- tions diffèrent génétiquement d'une population géographiquement plus distante (Postojna; $D_{\mathrm{Nei}}=0.49$ ). Le niveau de différenciation génétique montre que les populations occidentales et sud-orientales représentent des lignées distinctes depuis le Miocène supérieur; on considère tout de même qu'elles appartiennent à une même espèce. Le taxon nouvellement décrit est connu d'un territoire fort restreint, et il est apparemment rare; bien que protégé par la loi. $P$. a. parkelj $\mathbf{n}$. ssp. est menacé par la pollution industrielle.

\section{History, habitat, and distribution}

The history of the name Proteus goes back to Valvasor (1689) who mentioned the species in his treatise "Die Ehre des Herzogtums Crain". With its discovery in the Postojna caves in Central Slovenia by Jeršinovic von Loewengreif in 1797 (Fitzinger, 1850) Proteus became the first known specialised cave animal.

The normal habitat of Proteus is cave waters, but most places where it was found were in the open when occasionally specimens were washed out of the caves after heavy rainfall. J.N. Laurenti, who formally described the species in a monotypic genus

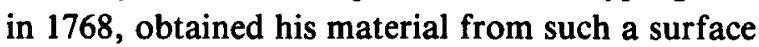
location in Cerknica near the Postojna caves.

The known distribution of Proteus anguinus encompasses the Dinaric karst almost entirely, from the lower reaches of the Isonzo-Soca River in Italy in the northwest to the river Trebisnjica in Hercegovina in the southeast. Altogether almost 200 localities are known (Sket, 1983; Sket \& Aljancic, in prep.).

Proteus is highly specialised troglomorphic, 


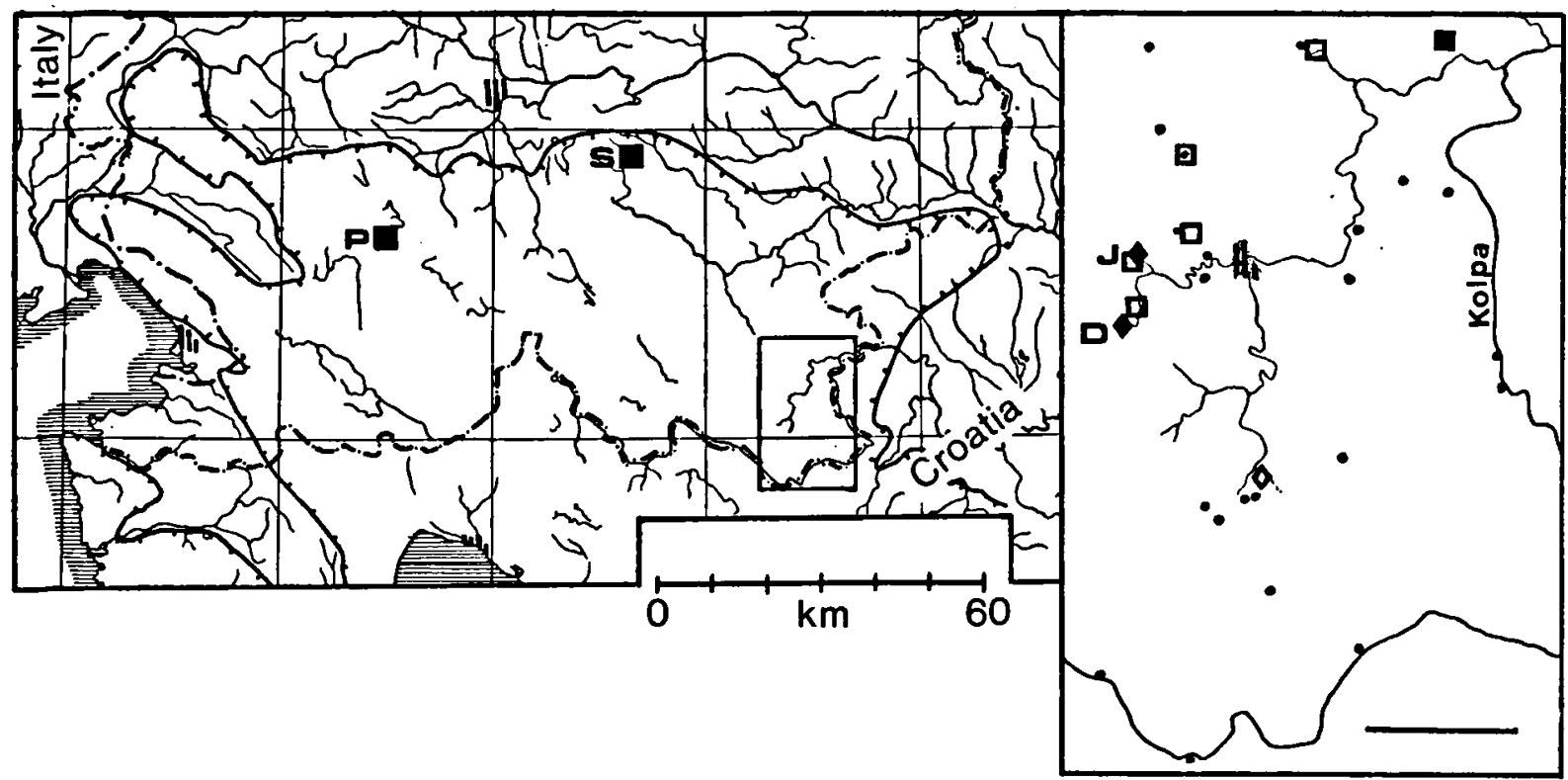

Fig. 1. Southern Slovenia with the area of Dinaric Karst indicated by a denticulated line. Solid squares refer to documented records of white $P$. a. anguinus populations; solid diamonds refer to documented records of $P$. $a$. parkelj; open symbols refer to reports that require confirmation. The insert highlights the Bela Krajina, with black dots documenting places of access to hypogean waters such as springs and caves. Scale bar is $5 \mathrm{~km}$. D, Dobličca; J, Jelševnik; P, Planina (Postojna and Planinska Jama); S, Stična, with the springs Vir and Rupnica. Three vertical bars indicate (from left to right) the cities Trieste, Ljubljana, and Crnomelj.

strictly neotenic and shows limited morphological variation. Normally Proteus is blind and at the most weakly pigmented. However, it is able to synthesise dark pigments and reared in the light it may gradually become dark or even black (Aljančič et al., 1986). During larval development, the initial eye development is retarded; later on in life the eyes degenerate and become covered by skin (Durand, 1973). Attempts to induce metamorphosis failed (Pehani \& Seliškar, 1941).

No obvious characters exist that suggest strong intraspecific differentiation. The only serious attempt to elaborate upon the taxonomy of Proteus was by Fitzinger (1850) who described seven species under the genus name Hypochthon (see also Schreiber, 1912). Of all those taxa only $H$. zoisii has been accepted by some (Mertens \& Müller, 1940) at the subspecies level as Proteus anginus zoisii Proteus anguinus is the only living representative of the genus. The most likely sister taxon to Proteus is the genus Necturus from the New World (Duellman \& Trueb, 1986).

The first documented finding of a "black" Proteus in nature is that by members of the Institute for
Karst Research (Slovenian Academy of Sciences and Arts). One black specimen with developed eyes and unusual body proportions was caught in the Dobličica spring, near Črnomelj in southeastern Slovenia on October 18, 1986. As Proteus is popular among Slovenes, this finding resulted in a lot of publicity, mostly at the popular level (Aljancic et al., 1986; Istenič \& Bulog, 1986; Istenič, 1987; Hodalič, 1993). Another black specimen was sighted and photographed by Miss M. Zlokolica below the Jelševnik springs, some $2.5 \mathrm{~km}$ north of Dobličica, on April 21, 1990. In the period up to 1992 a sufficient number of specimens $(n=15)$ was obtained to allow morphometric and other investigations.

For the purpose of the present paper we will refer to densely pigmented Proteus as "black" and to unpigmented and slightly pigmented ones as "white".

\section{Material and methods}

Samples of Proteus used or mentioned in this study originate mainly from the following Slovenian localities: (1) the $\mathrm{Na}$ Trati 
spring at Jelsevnik near Crnomelj in the Bela Krajina (in the text usually referred to as "Jelక̌vnik"), (2) the Vir and Rupnica springs, both at Stixna, $1.7 \mathrm{~km}$ apart, $25 \mathrm{~km}$ E.S.E. of Ljubljana (together referred to as "Sticna"), (3) the Planinska Jama cave at Planina, near Postojna which forms part of the PostojnaPlanina cave system (referred to as "Planina") (Fig. 1).

Only specimens that were damaged or that died in captivity have been preserved, except for specimens that were sacrificed for biochemical taxonomic analysis (see below). As a consequence the quality of most of the material is rather poor. For histological studies the specimens were fixed in a $2 \%$ solution of glutaraldehyde and later transferred to $70 \%$ ethanol. One skeleton was prepared by maceration of the carcass in a weak solution of $\mathrm{KOH}$ and its skeleton then dyed by alizarin. Other specimens or parts thereof have been cleared in $\mathrm{KOH}$ and glycerol, stained with alizarin and preserved in glycerol with thymol, following Humason (1967). Eight black Proteus are preserved in 70\% ethanol and at present six are kept alive at the Department of Biology of the Biotechnical Faculty, University of Ljubljana.

Some osteological details were studied on cleared specimens from Planina and from Luknja near Novo Mesto. In addition, tail tips of some specimens from Vir, Luknja, and Planina were cleared to allow an osteological study. Data on pigmentation were taken from live as well as from preserved specimens. Eyes were measured in some intact specimens and in a skinned head. Data on the structure of the eyes and skin were obtained by electron microscopy (Bulog, 1992). The morphology of the gills was studied in detail but since preliminary observations pointed to a marked phenotypic plasticity, the quantitative aspects were not further taken into consideration. X-ray photographs were taken by standard clinical equipment. For most specimens settings were 31-32 kV at $120 \mathrm{~mA}$ on a Siemens "Selenos-4", with a glass plate below serving as a filter. In newly collected specimens listed in Table II, photographs were taken using a Siemens "Polydoros 80" apparatus set at 40-41.5 kV and 1.6-2.5 mA. We did not succeed in obtaining useful pictures of the tiny tail vertebrae, neither by X-ray photography, nor by nuclear magnetic resonance.

A specimen of Necturus sp. of unknown provenance and its $\mathrm{X}$-ray image were used for morphological comparison of the eyes and the backbone. Two adult specimens of Triturus alpestris (Laurenti, 1768) from the Kamniške Alps in Slovenia and two specimens of neotenic phenotype from Trnovičko Jezero, Maglić Mts., Montenegro were cleared for the same purpose.

A series of 82 individuals, including specimens stored in the collections of the Naturhistorisches Museum, Vienna, and the University of Ljubljana, originating from four localities (Jelševnik, Planina, Rupnica, and Vir) were subjected to the measurement of the following eight variables: total length from the tip of the snout to the tail tip (L); head length from the tip of the snout to the line connecting the bases of the most anterior gills (Lc); head width at the point where head width is largest (Ltc); pre-pedal length from the tip of the snouth to the anterior legs (LaP); trunk length between the hind side of the anterior and the fore side of the posterior leg $(\mathrm{LiE})$; the length of the anterior and the posterior legs from their point of insertion to the tip of the longest toe on the perpendicularly stretched leg $(\mathrm{PaL}, \mathrm{PpL})$, and finally tail length from the hind side of a posterior leg to the tip of the tail (Lcd). Measurements were taken to the tenth of a mm using vernier callipers. Presented values are rounded off to their integer values. It should be noted that in soft tissues and in contracted preserved material the precision of the measurements may be diminished.

Two meristic measurements were also taken: (1) In fresh and alcohol-preserved material the number of myomeres (Myo) was counted between both pairs of legs. (2) The number of vertebrae (Ver) from the atlas up to and including the last vertebra before the pelvic girdle (ilium) was determined from X-ray photographs (see Plate I for an example) or counted directly in disarticulated and cleared specimens. Some ambiguity exists in counting the number of vertebrae towards the posterior end of the animal because the cartilaginous pelvic girdle and its attachment to the backbone in particular, is not resolved in X-ray photographs. Not surprisingly, both meristic characters proved highly correlated (cf. Romer \& Parsons, 1977), with a product-moment correlation coefficient of 0.70 . Because neither data set was complete, for three specimens the vertebrae count was estimated from the regression equation of Ver versus Mio. Teeth counts were not routinely performed, since this would require a partial dissection of precious specimens. Instead we used the data of Dolivo-Dobrovolsky (1926) after comparison with some of our own specimens in order to confirm the reliability of the published data.

At its 18th to 20th year, when Proteus matures and starts reproducing, growth has not yet completely ceased (Durand \& Delay, 1981). By consequence, absolute morphometric values are of limited use for comparative purposes. $L$ was therefore taken as a reference value for each of the continuous variables in order to reduce the effect of variation in individual size. In addition to a univariate character by character analysis using analysis of variance, the "Wolterstorff Index" (WI $=100 \times$ $\mathrm{LiE} \times \mathrm{Pa}^{-1}$ (Wolterstorff, 1923; Arntzen \& Wallis, 1993)) was calculated. A Principal Component Analysis (PCA) including a posteriori comparisons among localities was performed on ln-transformed data. A further analysis was carried out using Discriminant Analysis on a priori grouped specimens with locality as the independent variable. The statistical analyses were carried out using the SYSTAT 5.1 software package (Wilkinson, 1989).

Blood, liver, heart, stomach, and a strip of muscle from the ventrolateral side (in Proteus) or from the tail (in Mertensiella and Triturus, see below) were dissected from freshly sacrificed animals. Erythrocytes were removed from the blood by brief centrifugation. The plasma supernatant was diluted with an aliquot volume of $40 \%$ sucrose. Other tissues were ground in homogenising buffer $\left(0.1 \mathrm{M}\right.$ Tris, $10^{-3} \mathrm{M}$ EDTA and $5 \times 10^{-5}$ $M$ NADP, adjusted to $\mathrm{pH} 7.0$ with $\mathrm{HCl}$ ) and centrifuged. The aqueous supernatant was decanted and stored at $-70^{\circ} \mathrm{C}$ for future electrophoresis.

Polyacrylamide slab gel electrophoresis and staining of plasma 
Table I. Electrophoretic conditions for 26 protein systems, corresponding to 40 loci, examined in the genera Proteus, Mertensiella, and Triturus. Starch buffers are A: Tris-citrate pH 6.0 (XIII); B: Tris-citrate pH 7.0(I); C: Tris-citrate pH 8.0(V); D: Lithiumhydroxide-triscitrate pH 8.1 (X); E: Tris-malate $\mathrm{pH} 7.4$, electrode buffer is $0.22 \mathrm{M}$ Tris, $0.10 \mathrm{M}$ Maleic acid, $0.01 \mathrm{M}$ EDTA and $0.01 \mathrm{M} \mathrm{MgCl}_{2}, \mathrm{gel}$ buffer is electrode buffer diluted at 1:10; F: Tris-EDTA-borate pH 8.9 (Ayala et al., 1972); G: Discontinuous tris-citrate-borate pH 8.2-8.7 (Poulik, 1957). Roman numerals refer to the buffer systems of Shaw \& Prasad (1970). PAGE refers to acrylamide gels according to Maurer (1971: Table 4.1). Tissues used are: $H=$ heart, $L=$ liver, $M=$ muscle, $P=$ plasma, and $S=$ stomach.

\begin{tabular}{|c|c|c|c|c|}
\hline Protein & E.C. No. & Locus & $\begin{array}{l}\text { Buffer } \\
\text { system }\end{array}$ & $\begin{array}{l}\text { Tissue } \\
\text { extract }\end{array}$ \\
\hline Acid phosphatase & 3.1.3.2 & $A c p h-2$ & $\mathbf{A}$ & $\mathbf{L}$ \\
\hline Adenosine deaminase & 3.5.4.4 & Ada & C & $\mathbf{L}$ \\
\hline Albumin & - & $A l b$ & PAGE & $\mathbf{P}$ \\
\hline Alcohol dehydrogenase & 1.1.1.1 & Adh-1, Adh-2 & C & $\mathbf{L}$ \\
\hline Catalase & 1.11.1.6 & Cat & D & $\mathbf{L}$ \\
\hline Esterase & 3.1.1.1 & Est-1, Est-2 & D & $\mathbf{P}, \mathbf{L}$ \\
\hline General Protein & - & $G P-2$ & PAGE & $\mathbf{P}$ \\
\hline Glucose 6 phosphate dehydrogenase & 1.1.1.49 & $G 6 p d-1, G 6 p d-2$ & C & $\mathbf{L}$ \\
\hline Glucose dehydrogenase & 1.1.1.47 & $G d h$ & C & $\mathrm{L}$ \\
\hline Glucose phosphate isomerase & 5.3 .1 .9 & Gpi & $\mathbf{A}$ & $\mathbf{L}$ \\
\hline Glutamate oxaloacetate transaminase & 2.6.1.1 & Got-1 & G & $\mathbf{L}$ \\
\hline$\alpha$-Glycerophosphate dehydrogenase & 1.1.1.8 & $G l y-1, G l y-2$ & $\mathbf{C}$ & $\mathbf{L}$ \\
\hline Isocitrate dehydrogenase & 1.1.1.42 & $I c d-1, I c d-2$ & $\mathbf{E}$ & $\mathbf{L}$ \\
\hline Lactate dehydrogenase & 1.1.1.27 & $L d h-1, L d h-2$ & A,B & $\mathbf{H}, \mathbf{M}$ \\
\hline Leucine aminopeptidase & 3.4 .11 & Lap & $\mathbf{F}$ & $\mathbf{L}$ \\
\hline Malate dehydrogenase & 1.1.1.37 & $M d h-1, M d h-2$ & $\mathbf{A}$ & $\mathbf{L}$ \\
\hline Malic enzyme & 1.1 .1 .40 & $\mathrm{Me}$ & C & $\mathbf{L}$ \\
\hline Mannose phosphate isomerase & 5.3.1.8 & $M p i-1, M p i-2$ & $\mathrm{C}$ & $\mathbf{L}$ \\
\hline NADH dehydrogenase & 1.6.99.2 & Nadhdh-I, Nadhdh-2 & G & $\mathbf{L}$ \\
\hline Peptidase & $3.4 .11-13$ & Pep-1, Рep-2, Рep-3 & D & $\mathbf{S}$ \\
\hline Phosphoglucomutase & 2.7.5.1 & $P g m-1, P g m-2$ & $\mathbf{A}$ & $\mathbf{L}$ \\
\hline Phosphogluconate dehydrogenase & 1.1.1.44 & Pgd & $\mathbf{A}$ & $\mathbf{L}$ \\
\hline Sorbitol dehydrogenase & 1.1.1.14 & $S d h$ & $\mathbf{A}$ & $\mathbf{L}$ \\
\hline Superoxide dismutase & 1.15 .1 .1 & Sod-1, Sod-2 & $\mathbf{E}$ & $\mathbf{L}, \mathbf{M}$ \\
\hline Transferrin & - & $\operatorname{Trf}$ & PAGE & $\mathbf{P}$ \\
\hline Xanthine dehydrogenase & 1.1.1.204 & $X d h-1, X d h-2$ & $\mathbf{E}$ & $\mathbf{L}$ \\
\hline
\end{tabular}

proteins were performed according to Maurer (1971). Enzyme electrophoresis was performed using Connaught starch in horizontal gels. The enzymes were visualised by standard histochemical techniques (Shaw \& Prasad, 1970; Harris \& Hopkinson, 1976) with few modifications. Proteins assayed and buffer systems used are presented in Table I. Presumptive loci and alleles (electromorphs) were assigned numbers and letters, respectively, when more than one zone of activity was observed in sequence starting from the most anodally migrating forms. For two enzyme systems, ACPH and GOT, two zones of activity were observed, but only one could be consistently scored. These loci were designated Acph-2 and Got-1, respectively.

Three different enzymes with protein digesting properties were resolved. PEP-3, anodally migrating in the Proteus samples, showed substrate specificity for the tripeptide LeucylGlycyl-Glycine, while the cathodally migrating PEP-1 and PEP-2 were most clearly resolved when the dipeptide LeucylTyrosine was supplied as a substrate. Three plasma proteins were scored, although in one unidentified protein (GP-2) the corresponding electromorph(s) could not be identified for one taxon. The faster anodally migrating fractions were identified as Albumin and Transferrin, based on their phenotypic characteristics and their representation in the most concentrated fraction in the plasma (cf. Rafinski \& Arntzen, 1987).

To assess the degree of genetic variability within the Proteus individuals, populations, and the outgroup taxa, we counted the number of polymorphic loci and calculated the unbiased estimate for mean heterozygosity based on Hardy-Weinberg expectations $\left(H_{e}\right)$ and the accompanying standard error (Nei, 1987). In order to assess the degree of genetic differentiation across populations we calculated the genetic distance measure of Nei and its standard error $\left(D_{\mathrm{Nei}} ; \mathrm{Nei}, 1972\right)$, which may, for low and intermediate values, be linearly correlated to time (Nei, 1987).

The matrix of $D_{\mathrm{Nei}}$ was converted into a phenogram using the UPGMA method (Sneath \& Sokal, 1973). A main objection against this method is that the phenogram can be interpreted in 
a phylogenetic sense only when rates of evolutionary change are homogeneous across the phyletic lines, a condition almost never satisfied in reality. This strong and unreal assumption of uniformity of evolutionary rates is relaxed in the distance-Wagner procedure (Farris, 1972). This procedure requires a distance measure which is metric. Since Nei's distance is not metric, we applied the widely used Rogers' genetic distance $D_{\mathrm{R}}$ (Rogers, 1972). From the resulting undirected trees the most parsimonious one, in terms of tree length, was selected. For an evolutionary interpretation the undirected trees have to be rooted. As appropriately preserved specimens of the genus Necturus, the assumed sister group of Proteus, were not available for comparison, instead seven Triturus cristatus (Laurenti, 1768) from Canterbury and Peterborough, United Kingdom and two Mertensiella caucasica (Waga, 1876) from near Rize in Turkey were used as outgroups.

To distinguish on the generated tree the branches for which the data show strong support from the areas in which the branching order is more uncertain, we applied the jack-knife test as advocated by Lanyon (1985) for distance data. The computer programme employed for analysis was the micro-computer version of BIOSYS-1 (Swofford \& Selander, 1981).

The locality Jelševnik was visited after heavy rainfalls, when local inhabitants notified us about the welling up of the so-called "boiling-holes". To obtain an impression of the composition of the cave fauna that may serve as prey to Proteus, drift nets of various size and mesh width were placed immediately below the holes as long as the discharge continued (generally from one to three days). The catches were generally very small and no animals at all were obtained from the main Jelsevnik spring. Since only empty gastropod shells could be collected from sediments of the outflow, it is not possible to establish their origin precisely.

\section{Results}

\subsection{Description of the black Proteus}

Anticipating the discussion we assign taxonomic status to the black Proteus that will be named Proteus anguinus parkelj Sket \& Arntzen.

Material. - Holotype: coll. nr. J8 is a female from Na Trati, Jelševnik near Crnomelj, Slovenia (plate I), preserved in ethanol. Paratypes: same locality, six specimens (J1-J3, J6-J7, J9) and one embryo/larva of $21 \mathrm{~mm}(\mathrm{~J} 10)$, preserved in ethanol. One specimen cleared and stained (J5) and one disarticulated skeleton (J4) are preserved in glycerol. Others: one specimen (D1) from Doblicica spring, Doblixe near Crnomelj, is ethanol preserved. All material is kept in the collection of the Department of Biology of the University of Ljubljana, Slovenia, except for J9, which is deposited in the Zoological Museum, Amsterdam, the Netherlands and stored under nr. ZMA Herp. 9239.
3.1.1 Etymology. - "Parkelj" is one of the Devil's names in Slovene Christian mythology. In Ljubljana, around St. Nicholas day, small "parkeljni" (plural of "parkelj") with a black body and a red tongue are sold. These allegedly hypogean creatures resemble the black hypogean amphibian with its red gills. Note that the ending " $j$ " of the word parkelj is not to be pronounced.

3.1.2 Diagnosis. - A dark pigmented and shortsnouted subspecies of $\boldsymbol{P}$. anguinus with externally visible eyes, a head with angular and convex lateral sides, a long trunk, short legs, and a short tail.

3.1.3 Description of the type series. - Holotype: morphometric characters, variability indices, and corresponding data for white Proteus a. anguinus can be taken from Table II. The dorsal and lateral parts of the body are almost completely black with a violet or brownish hue. In some specimens the colour is only very dark brown. The snout is broadly bordered black as soot, in some specimens with a pale or whitish triangle in the preocular region. Limbs pale with a dark patterning. Ventral side of the body pale with a bluish or pinky shade. Skin surface finely granulated in preserved specimens. An alcohol preserved specimen (D1) has retained a dark brownish black coloration for seven years. Gills red in live specimens, with dark brown principal branches.

The skin contains large quantities of pigment, mainly in the upper part of the dermis. The upper dermis also contains more numerous multicellular glands than is found in white specimens and Leydig cells are present in the epidermis (Bulog, 1991, 1992).

The eyes are small and externally visible as black dots that are surrounded by a white circle. The eye is covered by a distinct transparent conjunctiva but without lids or similar structures. The diameter of the conjunctiva is ca. $5 \%$ of the head length. The general structure of its bulb is similar to that in epigean amphibians with a well-developed retina. In a $190 \mathrm{~mm}$ long specimen from Doblicica, the bulb diameter was measured to $1.3 \mathrm{~mm}$ ( $7 \%$ of $\mathrm{Lc}$ ) and the diameter of its lens $0.2 \mathrm{~mm}$ (glutaraldehyde preparations for electron microscopy were made by 
Table II. Morphometric data (mm) for Proteus anguinus parkelj spp. n. from Jelševnik and $P$. a. anguinus from Planina, Rupnica, and Vir. $\mathbf{L}=$ total length; $\mathbf{L c}=$ head length; Ltc = head width; $\mathrm{LaP}=$ pre-pedal length; $\mathrm{LiE}=$ trunk length; PaL $=$ anterior leg length; $\mathrm{PpL}=$ posterior leg length; $\mathrm{Lcd}=$ tail length; $M$ yo = number of trunk myomeres; Ver = number of neck and trunk vertebrae; WI = Wolterstorff Index. Values in parentheses are estimated from the regression of Led versus $L$ and Ver versus Myo. Data are presented individually for all biochemically studied specimens and for the type series from Jelsevnik. Statistical data include the specimens measured by Kranjec (1981).

\begin{tabular}{|c|c|c|c|c|c|c|c|c|c|c|c|c|}
\hline Locality & $\begin{array}{l}\text { Specimen } \\
\text { number }\end{array}$ & $\mathbf{L}$ & Lc & Ltc & LaP & $\mathrm{LiE}$ & PaL & PpL & Led & Myo & Ver & WI \\
\hline \multicolumn{13}{|l|}{ Jelకevnik } \\
\hline & $\mathbf{J 1}$ & 227 & 27 & 16 & 31 & 130 & 14 & 13 & 64 & 31 & (33) & 10.8 \\
\hline & $\mathbf{J} 2$ & 247 & 26 & 16 & 32 & 138 & 14 & 12 & (69) & - & - & 10.1 \\
\hline & J3 & 240 & 25 & 17 & 34 & 140 & 16 & 13 & 67 & 32 & 35 & 11.4 \\
\hline & J5 & 205 & 23 & 14 & 31 & 120 & 13 & 11 & 55 & - & 34 & 10.8 \\
\hline & J7 & 199 & 20 & 12 & 27 & 113 & 13 & 10 & 57 & 30 & (33) & 11.5 \\
\hline & J8* & 276 & 28 & 17 & 37 & 158 & 16 & 13 & 78 & 30 & 34 & 10.1 \\
\hline & J9 & 232 & 24 & 16 & 30 & 135 & 14 & 13 & 65 & 33 & 35 & 10.4 \\
\hline & sample size & 7 & 7 & 7 & 7 & 7 & 7 & 7 & 6 & 5 & 4 & 7 \\
\hline & mean & 232.3 & 24.7 & 15.4 & 31.7 & 133.4 & 14.3 & 12.1 & 64.3 & 31.2 & 34.5 & 10.7 \\
\hline & SD & 26.0 & 2.69 & 1.81 & 3.15 & 14.6 & 1.25 & 1.22 & 8.19 & 1.30 & 0.58 & 0.57 \\
\hline & minimum & 199 & 20 & 12 & 27 & 113 & 13 & 10 & 55 & 30 & 34 & 10.1 \\
\hline & maximum & 276 & 28 & 17 & 37 & 158 & 16 & 13 & 78 & 33 & 35 & 11.5 \\
\hline \multicolumn{13}{|l|}{ Planina } \\
\hline & P5 & 235 & 26 & 17 & 35 & 118 & 19 & 16 & 75 & 27 & 31 & 16.1 \\
\hline & P6 & 255 & 30 & 17 & 37 & 129 & 19 & 20 & 82 & 28 & 31 & 14.7 \\
\hline & sample size & 54 & 54 & 54 & 54 & 54 & 54 & 54 & 54 & 54 & 53 & 54 \\
\hline & mean & 223.2 & 29.0 & 15.3 & 36.0 & 109.9 & 18.7 & 17.5 & 72.6 & 25.5 & 30.8 & 17.1 \\
\hline & SD & 26.6 & 3.47 & 2.40 & 4.02 & 14.1 & 2.07 & 2.15 & 9.29 & 0.79 & 0.51 & 1.20 \\
\hline & minimum & 147 & 19 & 9 & 24 & 72 & 13 & 12 & 48 & 24 & 30 & 13.8 \\
\hline & maximum & 299 & 37 & 23 & 46 & 152 & 24 & 23 & 100 & 28 & 32 & 19.6 \\
\hline \multicolumn{13}{|l|}{ Rupnica } \\
\hline & $\mathbf{R} \mathbf{1}$ & 270 & 31 & 19 & 42 & 133 & 25 & 21 & 90 & 25 & 29 & 18.8 \\
\hline & $\mathbf{R 2}$ & 225 & 24 & 16 & 31 & 111 & 18 & 15 & 77 & 26 & 31 & 16.2 \\
\hline & sample size & 7 & 7 & 7 & 7 & 7 & 7 & 7 & 7 & 7 & 7 & 7 \\
\hline & mean & 245.0 & 27.7 & 17.5 & 36.6 & 118.4 & 20.4 & 17.2 & 83.9 & 25.4 & 29.9 & 17.3 \\
\hline & SD & 40.6 & 4.82 & 3.37 & 6.45 & 21.1 & 3.40 & 2.53 & 11.7 & 0.54 & 0.69 & 1.64 \\
\hline & minimum & 188 & 23 & 14 & 29 & 88 & 16 & 15 & 67 & 25 & 29 & 15.7 \\
\hline & maximum & 294 & 34 & 22 & 45 & 144 & 25 & 21 & 102 & 26 & 31 & 19.7 \\
\hline \multicolumn{13}{|l|}{ Vir } \\
\hline & v7 & 219 & 24 & 15 & 32 & 108 & 19 & 17 & 76 & 27 & 31 & 11.1 \\
\hline & sample size & 14 & 14 & 14 & 14 & 14 & 14 & 14 & 14 & 14 & 14 & 14 \\
\hline & mean & 228.4 & 27.8 & 16.0 & 34.6 & 111.4 & 19.1 & 16.7 & 76.5 & 26.1 & 30.6 & 16.7 \\
\hline & SD & 34.7 & 3.90 & 2.61 & 4.55 & 16.9 & 3.08 & 2.00 & 12.8 & 0.66 & 0.65 & 1.95 \\
\hline & minimum & 154 & 21 & 11 & 26 & 76 & 14 & 14 & 49 & 25 & 29 & 11.1 \\
\hline & maximum & 285 & 34 & 20 & 41 & 138 & 23 & 20 & 100 & 27 & 31 & 18.7 \\
\hline
\end{tabular}

* Holotype.

Bulog (1991, 1992)). In a skinned specimen of 205 $\mathrm{mm}$, at $0.9 \mathrm{~mm}$ the eye bulb's diameter was $3.9 \%$ of Lc (ethanol preparation).

The head is slightly broader than the trunk and approximately $11 \%$ of the length of the body (L-
Lcd). In its postocular part the head is parallelsided, the short snout shaped as a trapezoid with rounded corners. The snout comprises on average $27 \%$ of Lc. Three pairs of subdermal muscular cushions (that we tentatively identify as the leva- 


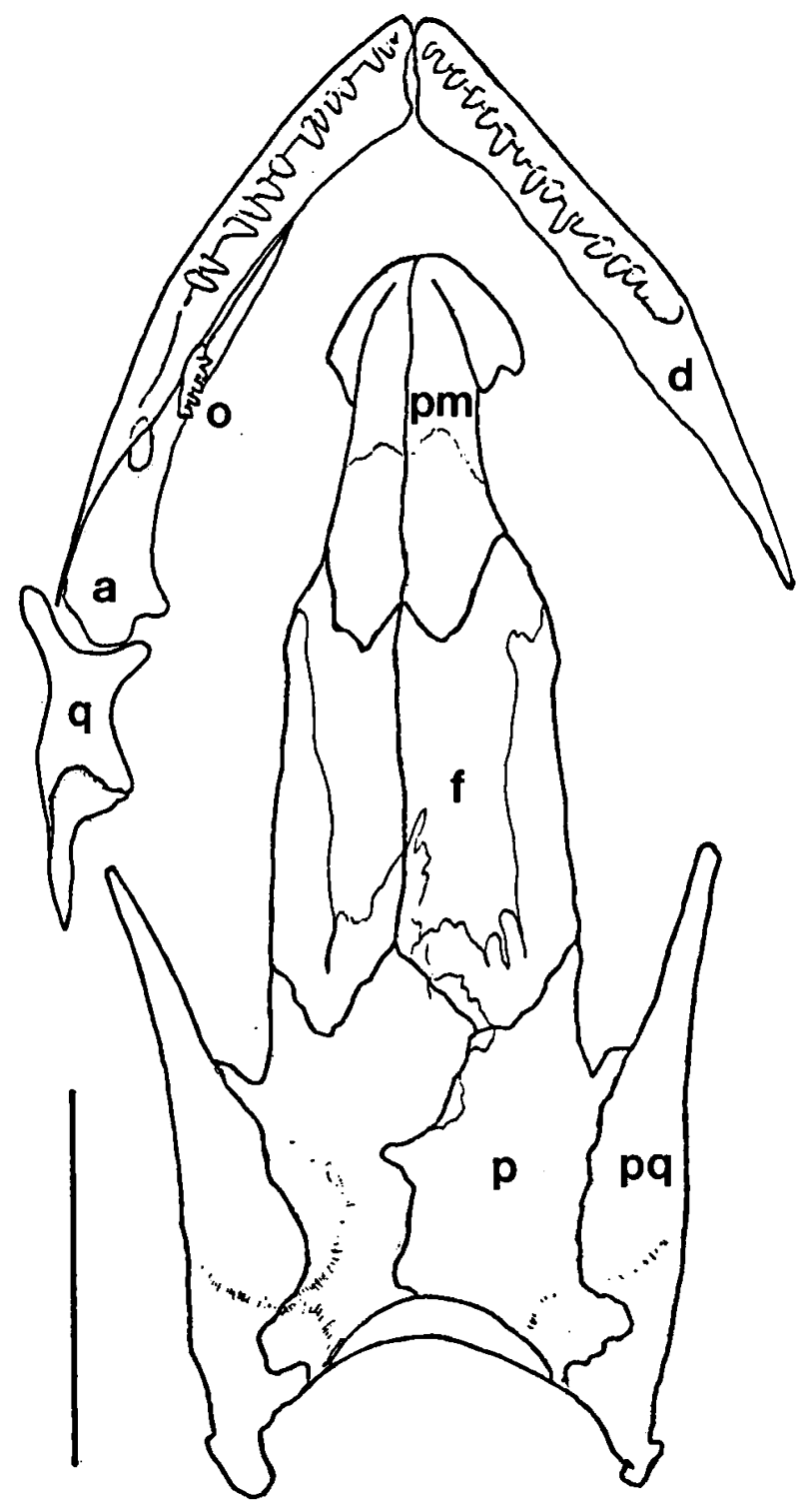

Fig. 2. Cranial and mandibular bones in Proteus anguinus parkelj from Jelševnik (specimen no. J4): a, angulare; d, dentale; f, frontale; o, operculare; $p$, parietale; pm, praemaxillare; pq, paraquadratum; q, quadratum. Scale bar $5 \mathrm{~mm}$.

tores mandibulae anteriores, levatores mandibulae externi, and depressores mandibulae posteriores) give the head a bulky appearance. Three pairs of short, bushy gills are well developed with a length of approximately $20 \%$ of Lc.

The trunk is cylindrical and anguilliform, on average $58 \%$ of the length of the body. The flanks
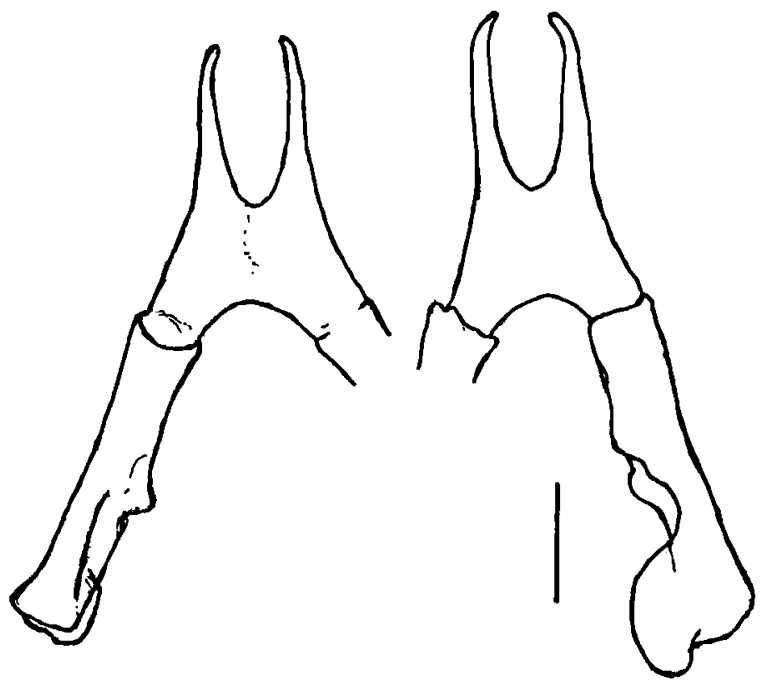

Fig. 3. Rostral part of the trabecula cranii with the anterior ossification and ethmoidal plaque in Proteus anguinus parkelj from Jelševnik (specimen no. J4). Scale bar $1 \mathrm{~mm}$.

of the body are running parallel with shallow furrows between the myomeres. The tail is short, comprising $28 \%$ of the entire body length and flattened laterally with the ventral and dorsal sides running almost parallel. The tail is as high or slightly higher than the trunk. The tail tip is broadly rounded or triangular with a rounded tip. The legs are short and slender. The anterior legs form on average $6 \%$ of the body length and have three toes. The posterior legs are slightly shorter and have two toes.

The skull is similarly built to that of white specimens (cf. Dolivo-Dobrovolsky, 1926) but proportioned differently. The neurocranium is wider, with a rostro-occipital length that is slightly less than the length of four pectoral vertebrae. The dentalia are placed in a wide arch, the largest width equals the lengths of 2.3 pectoral vertebrae. The ratio rostrooccipital length versus largest mandibular width averages 1.4 to 1 . The praemaxillaria are less than twice as long as wide (Fig. 2). The ethmoidal plaque in the only macerated skull that we possess has a rather peculiar shape with its rostral tines curved and with convergent tips (Fig. 3). In the frontalia the width versus length ratio averages at 0.6 to 1 . The frontalia slightly protrude along the praemaxillaria. The other bones of the neurocranium are 
Table III. Number of teeth observed in P. a. anguinus (four specimens from Luče and Stixna, according to Dolivo-Dobrovolsky, 1926) and in two specimens of $\boldsymbol{P}$. anguinus parkelj ssp. n. from Jelsevnik. Figures in parentheses denote the accessory smaller teeth standing outside the main row. Maximal numbers for white specimens are given separately for different combinations of principal (large) teeth and accessory teeth. In both taxa the opercular teeth may be arranged either in one or in two to three rows.

\begin{tabular}{|c|c|c|c|c|c|c|}
\hline & & \multicolumn{5}{|c|}{ Number of teeth on } \\
\hline & & Praemaxillare & Vomer & $\begin{array}{l}\text { Pterygo- } \\
\text { palatinum }\end{array}$ & Dentale & Operculare \\
\hline \multirow{2}{*}{$\begin{array}{l}\text { P. a. anguinus* } \\
\text { (minimum) }\end{array}$} & left & 7 & 22 & 5 & 22 & 6 \\
\hline & right & 7 & 22 & 6 & 21 & 5 \\
\hline \multirow{2}{*}{$\begin{array}{l}\text { P. a. anguinus* } \\
\text { (maximum) }\end{array}$} & left & 10 or $8(2)$ & $24(8)$ & 6 & 33 or $23(11)$ & 12 \\
\hline & right & $9(2)$ or $8(4)$ & $25(8)$ & 6 & $31(2)$ or $23(8)$ & 12 \\
\hline \multirow[t]{2}{*}{ P. a. parkelj } & J4-left & 5 & 19 & 4 & 19 & 7 \\
\hline & J4-right & 5 & 18 & 4 & 16 & $?$ \\
\hline \multirow[t]{2}{*}{ P. a. parkelj } & J5-left & 7 & 20 & 5 & $17(6)$ & 8 \\
\hline & J5-right & 8 & 22 & 5 & $17(4)$ & 6 \\
\hline
\end{tabular}

- According to Dolivo-Dobrovolsky (1926).

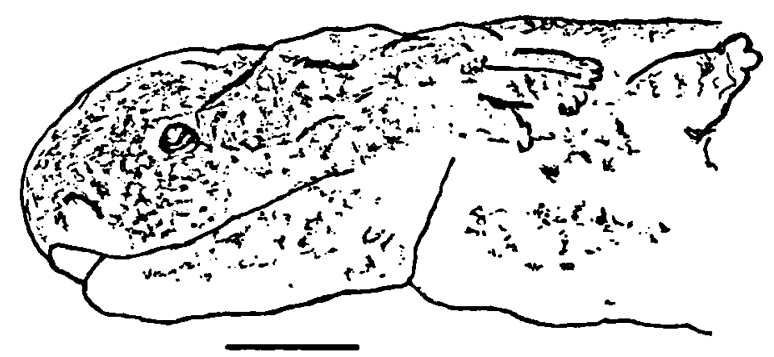

Fig. 4. Anterior part of embryonic larva of Proteus anguinus parkelj from Jelševnik (specimen no. J10) at Briegleb stage 21. Scale bar $1 \mathrm{~mm}$.

short and wide. There are fewer teeth than in the white morph, particularly so on the dentale. On the operculare, teeth are arranged in two or three rows. The dentale bears 16 to 19 teeth with another 4 to 6 small auxiliary teeth that are placed outside the main row (Table III).

The number of vertebrae between the skull and the posterior legs is 34 to 35 . The neck vertebrae are of the same length as the pectoral ones. The caudal vertebrae get gradually smaller till number XXIII or XXIV and are then followed by 3 to 5 rudimentary vertebrae that have no processes. Up to number XVII, the neural spine of the vertebrae is in the shape of a sharp and caudally extended triangle. The posterior spines form irregular trapezoidal crests and owing to the fact that they are remark- ably short, the vertebrae appear to be high.

A drifted larva of $21 \mathrm{~mm} \mathrm{~L}$ (specimen no. J10) was in Briegleb's developmental stage 21 (Fig. 4). It did not have the appearance of an active feeder. Its anterior legs are short and three-toed, the posterior ones are only short stumps without toes. The eye diameter is $8 \%$ of Lc. Ventrally the specimen is pale white. Dorsally it is densely speckled grey and less so on the sides.

As a result of the allozyme study, four alleles, $C a t^{\mathrm{b}}, C a t^{\mathrm{d}}, N a d h d h-1^{\mathrm{a}}$, and $P g d^{\mathrm{a}}$, were uniquely observed in black specimens.

\subsection{Comparison with related taxa}

3.2.1 General appearance, pigmentation, eyes, and gills. - Differently from the new subspecies, all Proteus from other populations than Jelsevnik and Doblixica exhibit a nearly white or pinkish skin, sometimes with pale yellow or pale grey patches. They only become dark after a long exposure to light.

In the stages immediately before or after the larval hatching (corresponding to an advanced stage 21 of Briegleb) the eye, with a diameter of 6 to $8 \%$ of Lc, is not evidently larger in $P$. a. parkelj than in $P$. a. anguinus (corresponding value is $8 \%$; mea- 

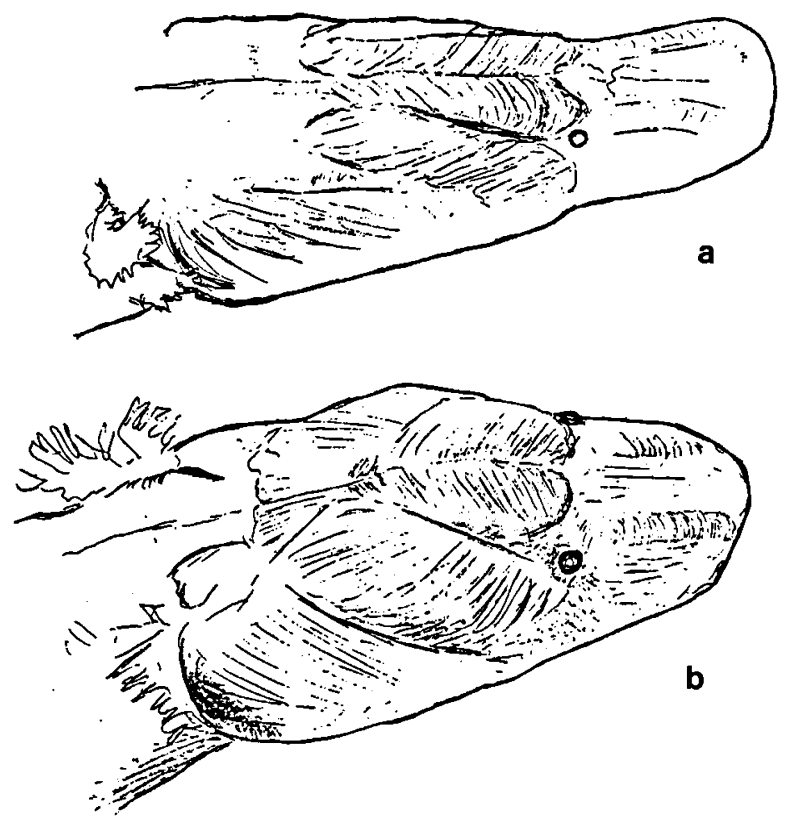

non has been supposed for Necturus (Conant, 1975). Compared to other Proteus populations, the gills in the black morph are of medium size.

3.2.2 Univariate morphometric and osteological comparisons. - The total length of the black Proteus ranged from $199 \mathrm{~mm}$ to $276 \mathrm{~mm}$, which falls within the range observed in our sample of white Proteus (range 147-299 mm).

For most measurements relative to $\mathrm{L}(\mathrm{Lc}, \mathrm{LaP}$, LiE, Lpa, Lcd) differences are found between populations. Relative Lc is smaller in the black Proteus than in the whites, while relative Ltc of both forms is nearly equal. The head differs strikingly in shape, more strongly than is brought about by the morphometric data. In the black morph the head is parallel-sided behind the snout. In the whites, due to a weaker musculature behind the eyes, the whole head has the shape of a long, truncated triangle

Fig. 5. Skinned heads of Proteus anguinus anguinus from Planina (a) and $P$. a. parkelj from Jelsevnik (b).

surements taken from a drawing in Briegleb (1962) and from photographs by Vandel \& Bouillon (1959) and Vandel et al. (1966)). The dark pigmentation in the embryo of $P$. a. parkelj seems to be only a little denser than in $P$. a. anguinus. The intense pigmentation of adult $P$. a. parkelj differs from most surface amphibians by the absence of a more vivid pattern of coloration. Also in the genus Necturus, sister group of Proteus, most species are without any bright coloration (cf. Conant, 1975; Behler \& Wayne King, 1979).

The eye in the black morph is small and without lids and superficially similar to that in Necturus. In the white morph the degenerated eyes are always covered by skin, although in some cases the eye might be shining through as a blackish dot. In a skinned specimen of white Proteus, the eye bulb's diameter at $2 \%$ of Lc was half that of the black specimen. As in other species with rudimentary eyes (Peters et al., 1973; Sket, 1985) the diameter of the rudiment is expected to be highly variable.

The length and ramification of the gills is variable within white populations. It may be that the varying oxygen concentration in the water affects increase or decrease of gill size. A similar phenome(Fig. 5). It even can be pear-shaped with concave flanks.

The relative length of the posterior legs, strongly correlated with relative head length (productmoment correlation coefficient $=0.94$ ), is smaller in the black morph than in the white morph. Making up on average $58 \%$ of $\mathrm{L}$, relative trunk length is larger in the black morph than in the white morph in which the corresponding value is $49 \%$. Correspondingly, in the black morph the absolute number of trunk vertebrae and myomeres is $4 ; 5$ or 6 higher than in the white morph.

Both pairs of legs are remarkably shorter in the black specimens than in the white ones. In both morphs the legs are similarly built with only three and two toes at the fore and hind limb, respectively, and with a simplified skeleton (cf. Aljančič \& Sket, 1964).

The tail is longer in white Proteus than in black Proteus. The tail shape shows a great interpopulational variability but some contour characters are quite constant within populations. In specimens from Planina, the tail with its crest is of the same height as the body, gradually lowering towards the tail tip, which is usually bluntly pointed. In specimens from Rupnica and Vir the tail is usually higher than the body. It does not narrow caudally and ends broadly rounded. In the black morph the tail tip is 

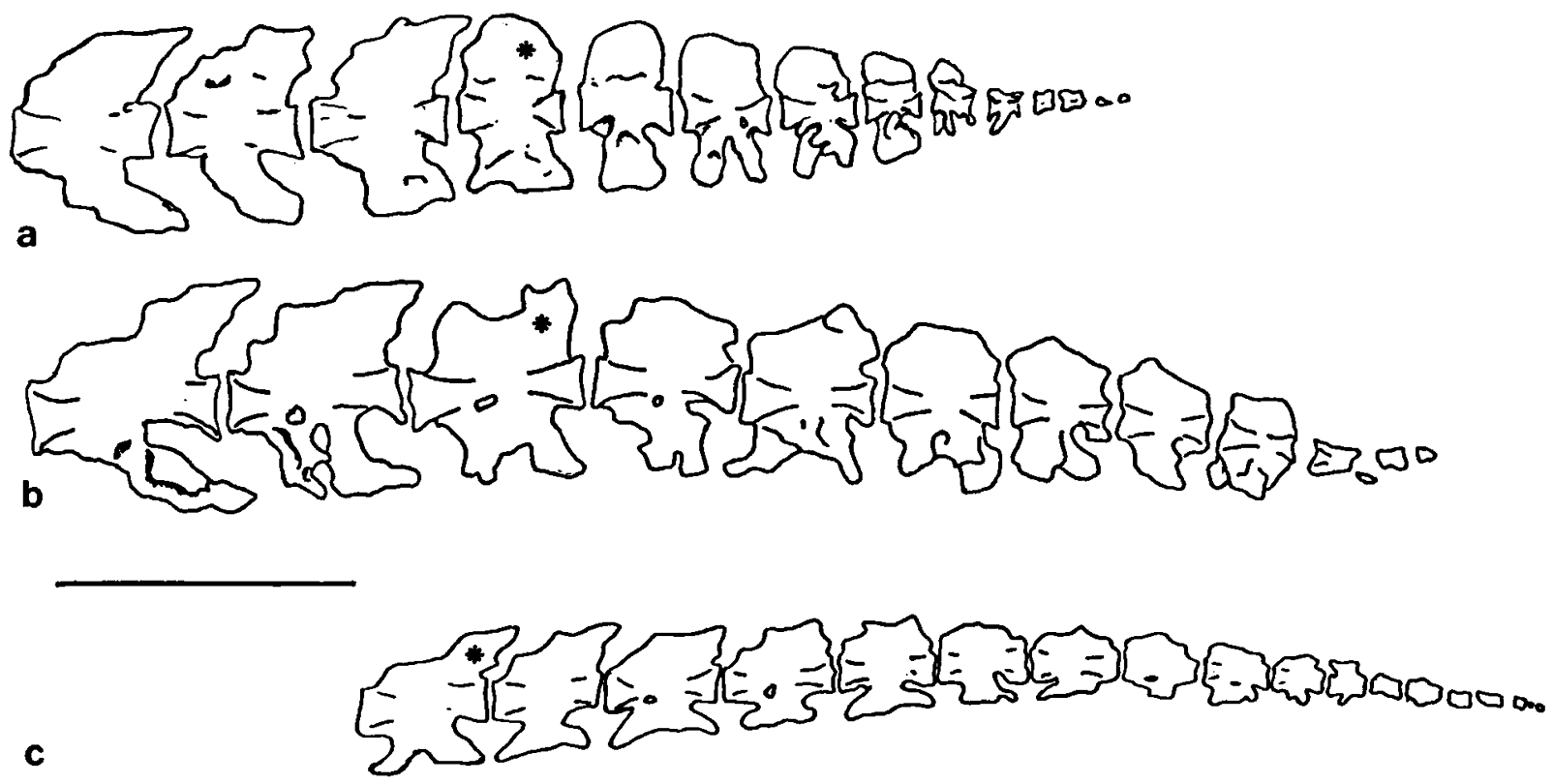

Fig. 6. Last caudal vertebrae in Proteus anguinus parkelj from Jelševnik (a) and P. a. anguinus from Vir (b) and Planina (c). The XVIIIth caudal vertebra is indicated by an asterisk. Scale bar is $5 \mathrm{~mm}$. The vertebrae are seen here from the same perspective as the heads in Fig. 5.

of a shape somewhere in between the recorded extremes.

In the skull of the black morph, the flat bones such as the parietalia, frontalia, and praemaxillaria are shorter or wider than in the white morph and the dorsally visible intercalations are shorter. Also some other bones (dentalia, paraquadrata) are differently shaped. The mandibular arch such as formed by the dentalia and angularia is wider than in the white morph. The number of teeth (Table III) is higher in the white morph than in the black morph, the difference being most pronounced in the dentale. The fossil relative Mioproteus caucasicus Estes \& Darevski with 10-12 teeth on its vomer (Estes \& Darevski, 1977) was markedly less toothed.

Some significant morphometric differences are also found between white Proteus populations from Planina and Sticna. The two Stična populations (Rupnica and Vir), however, are mostly indistinguishable.

In some white specimens the neck vertebrae are elongated, a feature that has not been observed in the black morph. Otherwise the trunk vertebrae are similarly shaped, and even in the black morph the vertebrae are not as stout as in Mioproteus caucasicus (cf. Estes \& Darevski, 1977; Estes \& Schleich, 1993). In Necturus as well as in all Proteus the centra and particularly the processes of the tail vertebrae are less well developed than in Paleoproteus (cf. Herre, 1935) or in neotenic and regular Triturus alpestris. In Proteus the centre of the individual vertebra is thinner, the dorsal spine and ventral process are narrower and the interspaces between subsequent vertebrae are substantially larger. Altogether their shape is variable. In black specimens, the caudal vertebrae get gradually smaller till the XXIIIrd or XXIVth and are followed by three to five rudimentary ones which are without processes (Fig. 6). In the white specimens from Vir the tail vertebrae are similar to the inspected black specimens, although markedly shorter. In the white specimens from Planina the vertebrae are lower and gradually diminishing in size towards the tip of the tail. One specimen has a chain of seven small, spineless vertebrae after the XXVIIIth that still bears spines (Fig. 6), while there are only three of such in another specimen. 
a

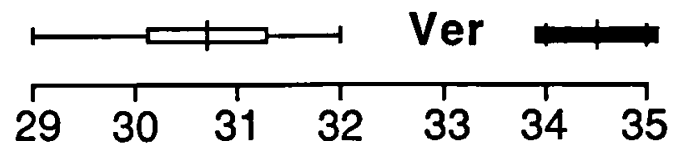

b

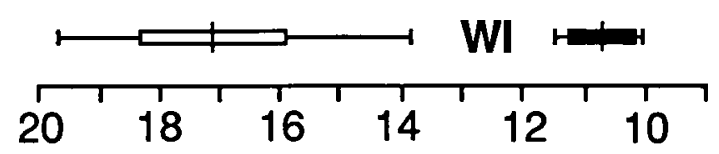

C

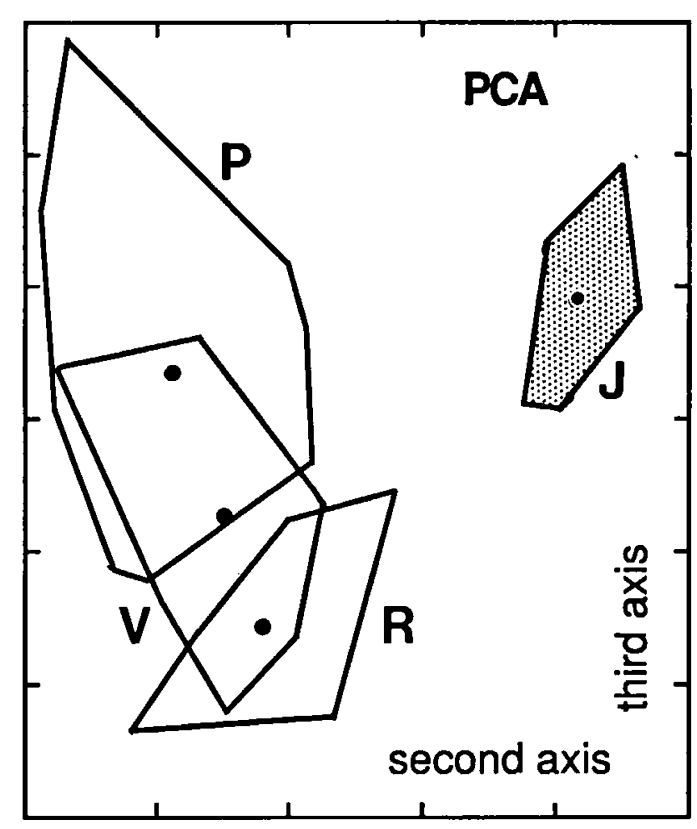

Fig. 7. Morphometrics of Proteus anguinus anguinus (outline symbols) and $\boldsymbol{P}$. a. parkelj (solid symbols). Upper part (a): univariate - number of trunk vertebrae (Ver); to the middle (b): bivariate - Wolterstorff Index (WI, details see text); lower part (c): second and third axes of a Principal Component Analysis (PCA) with centroids and convex outline polygons for $\mathbf{P}=\mathbf{P l a}$ nina, $\mathbf{R}=$ Rupnica, and $\mathrm{V}=\operatorname{Vir}(P$. a. anguinus) and $\mathrm{J}=$ Jelక̌nevnik (P. a. parkelj).

\subsubsection{Bivariate and multivariate morphometric} analysis. - The Wolterstorff Index is significantly different in the black and white morph of Proteus $(\mathrm{P}<0.001$; Table II). Similar to the situation in Triturus cristatus for which the WI was originally devised (Wolterstorff, 1923), the number of trunk vertebrae (Ver) is an equally good or better discriminatory feature than WI itself (Arntzen \& Wallis, 1993) (Fig. 7ab).

In the multivariate PCA all eight variables have high component loadings on the first axis, which is interpreted as representing general size. In line with the univariate analysis, size is not population dependent and not discriminatory for black versus white populations. The second axis is dominated by LiE, PaL, and PpL. Component loadings have contrasting signs, which means that animals have either a short trunk and long extremities, or a long trunk and short extremities. Hence the second PCA axis is essentially the same as the WI (Fig. 7bc).

On the third axis $\mathrm{Lc}$ and $\mathrm{PpL}$ dominate together with Lcd, with contrasting signs. This axis helps separating all populations from one another, especially those from Planina and Jelševnik from Rupnica and Vir. Plotting the second versus the third axis provides excellent overall separation of black and white specimens (Fig. 7c).

Discriminant analysis reveals that the morphometric differentiation for Planina versus Rupnica and Vir is not statistically significant, with 8 out of 54 specimens $(15 \%)$ wrongly classified. The populations of Rupnica and Vir are morphometrically virtually indistinguishable, with 7 out of 21 specimens $\mathbf{3 3 \%}$ ) wrongly classified.

3.2.4 Protein analysis. - In 23 different enzyme systems and three plasma proteins the variability could be consistently scored, with the exception of some loci in the outgroup taxa (two loci and four loci in Mertensiella and Triturus, respectively). Data on allelic composition for altogether 40 presumptive loci and the associated estimates of genetic variability of populations are presented in Table IV. The Mpi-I locus showed no variability over any of the assayed populations, while an additional 11 loci showed no variation across Proteus samples. In 12 loci, inter- but no intra-populational variation was observed for Proteus populations. The remaining 16 loci showed variability in at least one of the Proteus samples. The mean heterozygosity $\left(H_{e}\right)$ for the combined Proteus populations is $12.0 \pm 4.0 \%$, which is similar to the value found for $M$. caucasica $(11.2 \pm 3.3 \%)$ and substantially higher than $H_{e}=1.3 \pm 1.0 \%$ found for $T$. cristatus. Among Proteus populations $H_{e}$ ranges from $7.5 \%$ for the two studied specimens from Planina to $22.5 \pm 6.7 \%$ for the single individual from Vir. 
Table IV. Allelic composition for $\mathbf{4 0}$ gene loci (upper part) and measures of genetic variability (lower part) as observed in the genera Proteus, Mertensiella, and Triturus. Individuals from two populations of the latter taxon are pooled. Allelic composition in parentheses refers to single individuals. Missing data are indicated by a hyphen. $P$ is the number of polymorphic loci, $H_{e}$ is the average heterozygosity calculated on the basis of Hardy-Weinberg expectation and SE is the corresponding standard error (in percent values).

\begin{tabular}{|c|c|c|c|c|c|c|c|c|c|c|}
\hline \multirow{3}{*}{$\begin{array}{l}\text { Species } \\
\text { Locality } \\
\text { Reference no. }\end{array}$} & \multicolumn{7}{|c|}{$\begin{array}{l}\text { Proteus } \\
\text { anguinus }\end{array}$} & \multirow{2}{*}{\multicolumn{2}{|c|}{$\begin{array}{c}\begin{array}{c}\text { Mertensiella } \\
\text { caucasica }\end{array} \\
\begin{array}{c}\text { Azaklihoca Köyü, } \\
\text { Rize, Turkey }\end{array}\end{array}$}} & $\begin{array}{l}\text { Triturus } \\
\text { cristatus }\end{array}$ \\
\hline & \multicolumn{2}{|c|}{$\begin{array}{c}\text { Jelševnik, } \\
\text { Slovenia }\end{array}$} & \multicolumn{2}{|c|}{$\begin{array}{l}\text { Planina, } \\
\text { Slovenia }\end{array}$} & \multicolumn{2}{|c|}{$\begin{array}{l}\text { Rupnica, } \\
\text { Slovenia }\end{array}$} & \multirow{2}{*}{$\frac{\begin{array}{c}\text { Vir, } \\
\text { Slovenia }\end{array}}{\text { v7 }}$} & & & \multirow{2}{*}{$\begin{array}{c}\begin{array}{c}\text { Canterbury and } \\
\text { Peterborough, U.K. }\end{array} \\
\text { ZMA Herp. } 9199 \\
\text { and } 9200(n=7)\end{array}$} \\
\hline & J1 & $\mathbf{J} 2$ & P5 & P6 & $\mathbf{R} \mathbf{1}$ & $\mathbf{R 2}$ & & & & \\
\hline \multicolumn{11}{|l|}{ Locus } \\
\hline Acph-2 & $\mathrm{CC}$ & $\mathrm{CC}$ & DD & DD & $\mathrm{CC}$ & $\mathrm{CC}$ & $\mathrm{CC}$ & BB & BC & $\mathbf{A A}$ \\
\hline$A d a$ & BB & BB & BB & BB & BB & BB & BB & $\mathbf{A A}$ & $\mathbf{A A}$ & $\mathrm{CC}$ \\
\hline$A l b$ & DD & DD & $\mathrm{CC}$ & $\mathrm{CC}$ & DD & DD & CD & $\mathbf{A A}$ & $\mathbf{A A}$ & BB \\
\hline Adh-I & BB & BB & AA & $\mathbf{A A}$ & BB & BB & BB & - & - & - \\
\hline$A d h-2$ & DD & DD & $\mathbf{A A}$ & AA & AA & AD & AD & $\mathrm{CC}$ & $\mathrm{CC}$ & BB \\
\hline Cat & AB & AD & AA & $\mathbf{A A}$ & AA & AA & $\mathbf{A A}$ & - & - & $\mathrm{CC}$ \\
\hline Est-1 & $\mathrm{CC}$ & $\mathrm{CC}$ & $\mathrm{CC}$ & $\mathrm{CC}$ & $\mathrm{CC}$ & $\mathrm{CC}$ & $\mathrm{CC}$ & BB & BB & $\mathbf{A A}$ \\
\hline Est-2 & DD & DD & DD & DD & DD & $\mathrm{DE}$ & $\mathrm{CE}$ & BB & BB & $\mathbf{A A}$ \\
\hline$G P-2$ & BB & BB & BB & BB & $\mathrm{CC}$ & $\mathrm{CC}$ & $\mathrm{CC}$ & $\mathbf{A A}$ & AA & - \\
\hline G6pd-I & AA & AA & BB & BB & AA & AA & $\mathbf{A A}$ & DD & DD & $\mathrm{CC}$ \\
\hline G6pd-2 & BB & BB & $\mathrm{CC}$ & $\mathrm{CC}$ & BB & BB & BB & AA & AA & DD \\
\hline$G d h$ & AA & $\mathbf{A A}$ & AB & BB & $\mathbf{A B}$ & BB & BC & DE & DD & - \\
\hline$G p i$ & $\mathbf{A A}$ & AA & $\mathbf{A A}$ & $\mathrm{AB}$ & $\mathbf{A A}$ & $\mathbf{A A}$ & AA & DE & EE & $C C(C D, D D)$ \\
\hline Got-I & BB & BB & BB & BB & BB & BB & BB & BB & BB & $\mathbf{A A}$ \\
\hline$G l y-I$ & BC & $\mathrm{CC}$ & $\mathrm{CC}$ & $\mathrm{CC}$ & $\mathrm{CC}$ & $\mathrm{CC}$ & BC & $\mathrm{CC}$ & $\mathrm{CC}$ & $\mathbf{A A}$ \\
\hline Gly-2 & $\mathrm{CC}$ & $\mathrm{CC}$ & $\mathrm{CC}$ & $\mathrm{CC}$ & $\mathrm{CC}$ & $\mathrm{CC}$ & $\mathrm{CC}$ & BB & BB & $\mathbf{A A}$ \\
\hline$I c d-I$ & BB & BB & BB & BB & BB & BB & BB & $\mathrm{CC}$ & $\mathrm{CC}$ & $\mathbf{A A}$ \\
\hline$I c d-2$ & DD & BD & DD & DD & BB & BB & BB & $\mathrm{CC}$ & $\mathrm{CC}$ & $\mathbf{A A}$ \\
\hline$L d h-I$ & BB & BB & BB & BB & $\mathbf{A A}$ & $\mathbf{A A}$ & BB & $\mathrm{CC}$ & $\mathrm{CC}$ & $\mathrm{CC}$ \\
\hline$L d h-2$ & AB & $\mathbf{A B}$ & BB & BB & BB & BB & AA & $\mathrm{CC}$ & $\mathrm{CC}$ & DD \\
\hline Lap & $\mathrm{CC}$ & $\mathrm{CC}$ & $\mathrm{CC}$ & $\mathrm{CC}$ & $\mathrm{CC}$ & $\mathrm{CC}$ & $\mathrm{CC}$ & $\mathbf{A A}$ & AA & BB \\
\hline$M d h-1$ & BB & BB & BB & BB & BB & BB & BB & $\mathrm{CC}$ & $\mathrm{CC}$ & $\mathbf{A A}$ \\
\hline$M d h-2$ & DD & DD & $\mathrm{CC}$ & $\mathrm{CC}$ & DD & DD & DD & AA & AA & BB \\
\hline Me & BB & BB & BB & BB & $\mathbf{A A}$ & $\mathbf{A A}$ & $\mathbf{A A}$ & DD & CD & EE \\
\hline$M p i-I$ & AA & $\mathbf{A A}$ & $\mathbf{A A}$ & $\mathbf{A A}$ & $\mathbf{A A}$ & $\mathbf{A A}$ & $\mathbf{A A}$ & $\mathbf{A A}$ & $\mathbf{A A}$ & $\mathbf{A A}$ \\
\hline Mpi-2 & BB & BB & AB & $\mathrm{AB}$ & $\mathbf{A B}$ & AA & AB & DD & DD & $\mathrm{CC}$ \\
\hline Nadhdh-I & BB & AB & BB & BB & BC & BC & BB & $\mathrm{CC}$ & $\mathrm{CC}$ & DD \\
\hline Nadhdh-2 & $\mathbf{A A}$ & $\mathbf{A A}$ & AA & AA & AA & $\mathbf{A A}$ & AA & AA & $\mathbf{A B}$ & $\mathrm{CC}(\mathrm{CD})$ \\
\hline Pep-I & EE & DD & DD & DD & DD & DD & DE & $\mathrm{CC}$ & BC & $\mathbf{A A}$ \\
\hline Pep-2 & BB & BB & $\mathrm{CC}$ & $\mathrm{CC}$ & BB & BB & BB & AA & $\mathbf{A A}$ & - \\
\hline Pep-3 & DD & DD & $\mathrm{CC}$ & $\mathrm{CC}$ & DD & DD & DD & $\mathbf{A A}$ & $\mathbf{A B}$ & AA \\
\hline$P g m-I$ & $\mathrm{CC}$ & $\mathrm{CC}$ & AC & $\mathrm{AC}$ & AC & AC & BC & $\mathrm{CC}$ & $\mathrm{CC}$ & DD \\
\hline Pgm-2 & BB & BB & BB & BB & BB & BB & BB & DD & CD & $\mathbf{A A}$ \\
\hline Pgd & $\mathbf{A A}$ & BB & BB & BB & BB & BB & BB & DE & $\mathrm{DD}$ & $\mathrm{CC}$ \\
\hline$S d h$ & BC & BC & BC & BC & BB & BC & $\mathrm{CC}$ & DD & DD & $\mathbf{A A}$ \\
\hline Sod-1 & $\mathrm{CC}$ & $\mathrm{CC}$ & $\mathrm{CC}$ & $\mathrm{CC}$ & $\mathrm{CC}$ & $\mathrm{CC}$ & $\mathrm{CC}$ & $\mathbf{A A}$ & $\mathbf{A A}$ & BB \\
\hline Sod-2 & $\mathrm{CC}$ & $\mathrm{CC}$ & DD & DD & $\mathrm{CC}$ & $\mathrm{CC}$ & $\mathrm{CC}$ & AA & AA & BB \\
\hline$T r f$ & BB & BB & BB & BB & $\mathrm{CC}$ & $\mathrm{CC}$ & $\mathrm{CC}$ & AA & $\mathbf{A A}$ & $\mathbf{A A}$ \\
\hline$X d h-1$ & $\mathbf{A A}$ & $\mathbf{A A}$ & $\mathbf{A A}$ & $\mathbf{A A}$ & $\mathbf{A A}$ & AA & $\mathbf{A A}$ & BB & BB & BB \\
\hline$X d h-2$ & BB & $\mathbf{A B}$ & BB & BB & BB & BB & AB & $\mathrm{CC}$ & $\mathrm{CC}$ & DD \\
\hline$P$ (individual) & 4 & 6 & 4 & 4 & 4 & 5 & 9 & 3 & 6 & $0-1$ \\
\hline$P$ (population) & \multicolumn{2}{|c|}{9} & \multicolumn{2}{|c|}{5} & \multicolumn{2}{|c|}{7} & 9 & \multicolumn{2}{|c|}{9} & 2 \\
\hline$H_{e} \pm \mathrm{SE}$ (population) & \multicolumn{2}{|c|}{$13.8 \pm 4.2$} & \multicolumn{2}{|c|}{$7.5 \pm 3.2$} & \multicolumn{2}{|c|}{$9.6 \pm 3.4$} & $22.5 \pm 6.7$ & \multirow{2}{*}{\multicolumn{2}{|c|}{$\begin{array}{l}11.2 \pm 3.3 \\
11.2 \pm 3.3\end{array}$}} & $1.3 \pm 1.0$ \\
\hline$H_{e} \pm \mathrm{SE}$ (species) & & & & 12.0 & & & & & & $1.3 \pm 1.0$ \\
\hline
\end{tabular}


a

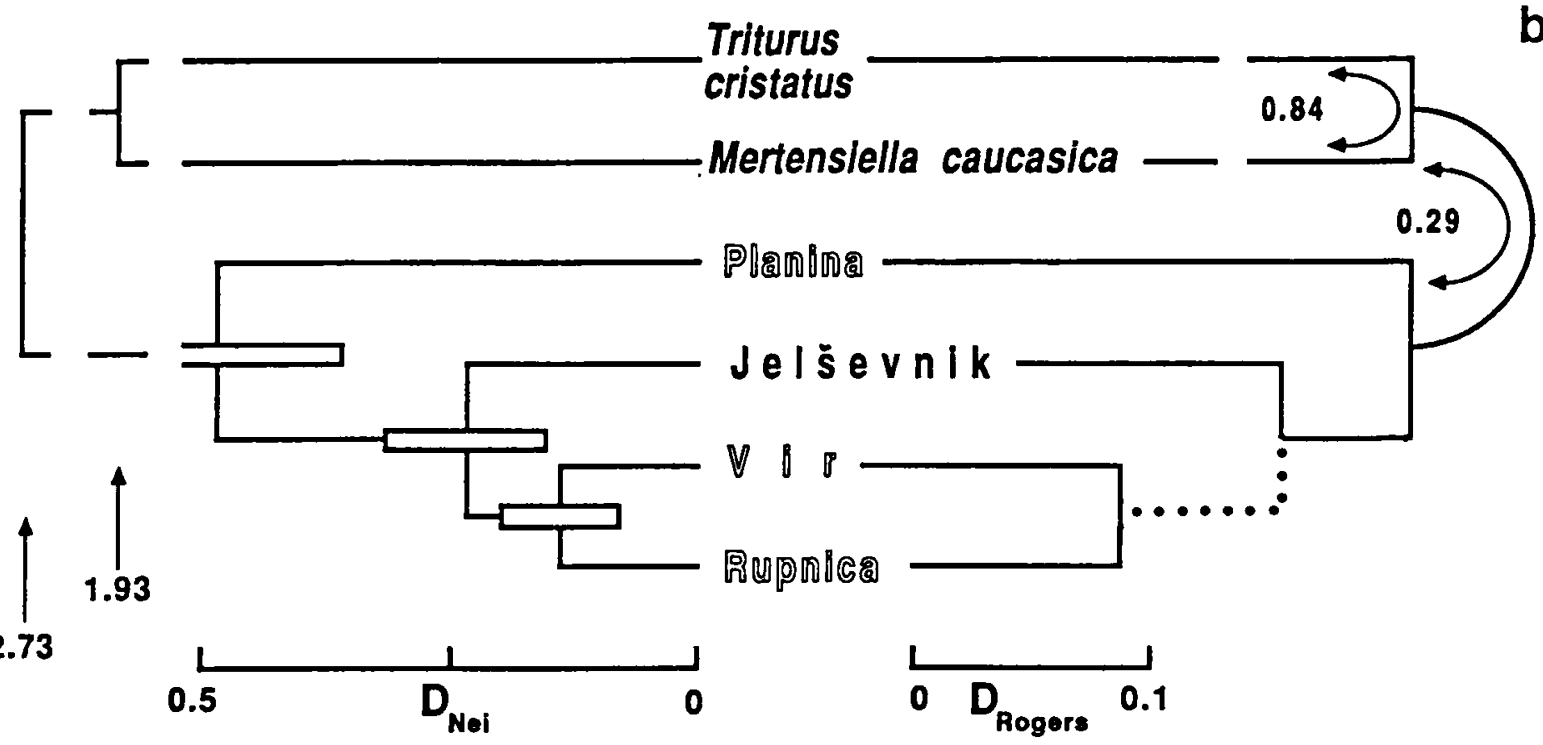

Fig. 8. To the left (a): UPGMA-dendrogram for four populations of Proteus (white morph with "outline" printed population name) based upon Nei's genetic distance as measured over 40 gene loci. Boxes indicate estimated standard error (Nei, 1987). The cophenetic correlation coefficient is $\mathbf{0 . 9 6}$. To the right (b): minimum length distance-Wagner tree on the basis of Rogers' genetic distance, rooted by the outgroup. Length of the tree is 0.62 (1.75 with outgroup taxa included); the cophenetic correlation coefficient is 0.99 . The interrupted line refers to a branch that is not robust under the jack-knife test (see text). Outgroup taxa Mertensiella and Triturus are included for comparison.

High values of $D_{\text {Nei }}(>1.8$; Fig. 8a) were obtained for all comparisons among Proteus and the outgroup taxa. Among Proteus populations relatively high values, with $D_{\mathrm{Nei}}$ ranging from $0.41-$ 0.56 , were obtained for comparisons involving the Planina population versus the others. Substantially lower values $\left(D_{\mathrm{Nei}}=0.23\right.$ and 0.24$)$ were recorded for comparisons between the black population from Jelševnik and the white populations from Rupnica and Vir, respectively. In all cases the standard error of these estimates, averaging at $32 \%$ of $D_{\mathrm{Nei}}$, is substantial and taking the standard error into account, the latter populations are not clearly separated (Fig. 8a). Using the UPGMA-method with the matrix of $D_{\mathrm{Nei}}$ results in a tree in which, seen from the root, the population from Planina branches off first, followed by Jelševnik and the two remaining clustering populations of Rupnica and Vir (Fig. 8a). Each of the jack-knife replicates supports this branching topology.

In the distance-Wagner tree that displays maximum parsimony the results are essentially the same. Inspecting the distribution of alleles, seven alleles $\left(A d h-2^{\mathrm{d}}, A l b^{\mathrm{b}}, G 6 p d-1^{\mathrm{a}}, G 6 p d-2^{\mathrm{b}}, I c d-2^{\mathrm{b}}, M d h-2^{\mathrm{d}}\right.$, and $\operatorname{Sod}-2^{\mathrm{c}}$ ) are potentially synapomorphic character states defining the grouping together - separate from Planina - of the Jelševnik and both Stična populations. Conflicting results and hence no robust phylogenetic resolution is found within the latter group (Fig. 8b).

Four alleles, $C a t^{\mathrm{b}}, C a t^{\mathrm{d}}, N a d h d h-1^{\mathrm{a}}$, and $P g d^{\mathrm{a}}$, were observed uniquely in the black Proteus from Jelševnik. Larger reference samples are required to find out whether or not these alleles are strictly autapomorphic. No loci with fixed alleles diagnostic for the black phenotype were observed. The populations from Rupnica and Vir $\left(D_{\mathrm{Nei}}=0.14\right)$ differ from one another most markedly on both $L d h$ loci.

\subsection{Ecology and reproduction of the black Proteus}

3.3.1 Habitat: abiotic parameters. - Up to the present, $P$. a. parkelj has only been documented for two localities near the town of Crnomelj in the Bela Krajina, which is in the southeasternmost part of Slovenia. The Dobličica and Jelševnik springs both discharge into the river Doblicica. They are situated 
in close proximity to one another (about $2.5 \mathrm{~km}$ apart), below the higher conical karst of the Poljanska Gora mountain ridge, with deeply set water channels. At an altitude of $150 \mathrm{~m}$ above sea level, the conical karst runs out in karst plains (Habič, 1991). On the plain, some small rivers flow on the surface while others are subterranean at a depth of several meters.

Dobličica is a permanent spring, rising from a deep pool of ca. $25 \mathrm{~m}$ diameter. There are some 5-11 m deep pits in the pool and its outflow. One black Proteus was caught in the outflow (not in the main spring) after a pumping experiment, which lowered the water level by two meters (Aljančic et al., 1986). Soon after, one of us (BS) inspected the spring by diving, but no amphibians were seen. At Jeľ̌evnik, there is a permanent limnocrene spring (called Jezero), similar to the Dobličica spring, and two associated groups of temporarily active "boiling holes", all within a reach of $150 \mathrm{~m}$. One black specimen was photographed below the southern group of boiling holes (Jamnice), while the typical series was caught at the northern group of holes of 1 to $100 \mathrm{~cm}$ in diameter ( $\mathrm{Na}$ Trati). The boiling holes eject water only a few times a year after heavy rains. When they are active or soon afterwards, black specimens have occasionally been found crawling around on the wet meadow or they were collected straight from a narrow hole in the meadow covering the karstified rock. The boiling holes at Jelševnik, as well as some accessory springs in the outflow of Dobličica, are probably fed by shallow local aquifers from the mountain or from the low karst zone. When active, they discharge large amounts of soil and some terrestrial animals. The presence of some epigean aquatic organisms in the drift of $\mathrm{Na}$ Trati suggests its partial origin from a surface stream in the background.

Physical and chemical parameters of the permanent springs were measured by Habič et al. (1990) on 17 occasions in spring and autumn of 19861990. In the permanent springs of Doblicica and Jeľ̌evnik, water temperature fluctuated between 10.0 and $11.3^{\circ} \mathrm{C}$ and temperatures in winter and summer are expected to deviate only marginally from this range (the extreme value of $14.8^{\circ} \mathrm{C}$ as mentioned for Dobličica is almost certainly errone- ous). The total hardness of the water ranged from 200 to $250 \mathrm{mg} \mathrm{CaCO}_{3} \times 1^{-1}$, with $\mathrm{Ca} \times \mathrm{mg}^{-1}$ ratios fluctuating. Oxygen content in Dobličica in the autumn of 1986 was near saturation. In May 1987, O-phosphates in Dobličica and Jelševnik springs corresponded to $0.01 \mathrm{mg} \mathrm{PO} \times 1^{-1}$. The dissimilar response of the springs to large scale water extraction and their differing chemical properties suggest complex and perhaps remote connections between these springs and the areas from where the water originates (Habič et al., 1990).

The hydrological complexity of the region can be illustrated by the situation at Jelševnik on November 1,1992 . While the temperature of the Jezero permanent spring and some of the boiling holes was in the range of 10.1 to $10.3{ }^{\circ} \mathrm{C}$, most holes discharged water of $11.2^{\circ} \mathrm{C}$, which was also the temperature of a nearby epigean stream. Close monitoring of the system, especially during upwelling periods, will be required to gain a proper understanding of the situation.

3.3.2 Associated biocoenoses and food. - Some stygobiont animals have been ejected from the permanent Dobličica and Jeľ̌evnik springs (Table V). Since $\mathrm{Na}$ Trati has no steady outflow and associated surface fauna, the surface animals in its drift either originate from an unidentified stream, or they are sucked in hydrodynamically from the main spring.

Upon capture, some of the Proteus gave up their stomach contents. Surprisingly, food items predominantly consisted of surface-dwelling prey species. Of these, the gastropod Vitrea sp., earthworms (Oligochaeta: Lumbricidae), and the chilopod Lithobius sp. may have actively penetrated subterraneously, but the aquatic gastropod Sadleriana fluminensis Kuester has been shown not to enter cave waters (Sket, 1970). These observations are in favour of suggestions that Proteus forages at night out in the open. In captivity, black Proteus are seen to be active and aggressive feeders that may, at least in an illuminated aquarium, attack and bite their white counterparts. Indeed, a violent attack on a white specimen during feeding has been registered on videotape. 
Table $V$. Fauna drifted from the habitat of Proteus anguinus parkelj: J, Jelsevnik Jezero; Ja, Jamnice; N1, Na Trati (big hole); N2, Na Trati (small holes). Gastropods were collected from sediments. Taxa of which the origin is difficult to determine, such as Nematoda, Oligochaeta, and Cyclopoida, are excluded (for details see text).

\begin{tabular}{|c|c|c|c|c|c|}
\hline & \multirow{2}{*}{ 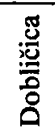 } & \multicolumn{4}{|c|}{ Jelševnik } \\
\hline & & $\mathbf{J}$ & $\mathbf{J a}$ & N1 & N2 \\
\hline \multicolumn{6}{|l|}{ Stygobiont and stygophilic species } \\
\hline \multicolumn{6}{|l|}{ Gastropoda } \\
\hline Belgrandiella fontinalis (Schmidt, 1847) & $\mathbf{x}$ & $\mathbf{x}$ & $\mathbf{x}$ & $\mathbf{x}$ & \\
\hline Belgrandiella sp. & $\mathbf{x}$ & $\mathbf{x}$ & $\mathbf{x}$ & $\mathbf{x}$ & \\
\hline Hauffenia cf. michleri Kušcer, 1932 & & & $\mathbf{x}$ & & $\mathbf{x}$ \\
\hline Hauffenia sp. & $\mathbf{x}$ & $\mathbf{x}$ & $\mathbf{x}$ & $\mathbf{x}$ & $\mathbf{x}$ \\
\hline Iglica cf. hauffeni (Brusina, 1885) & & $\mathbf{x}$ & & & \\
\hline Iglica sp. & $\mathbf{x}$ & & & & \\
\hline Sadleriana cavernosa Radoman, 1978 & $\mathbf{x}$ & $\mathbf{x}$ & $\mathbf{x}$ & & \\
\hline Sadleriana sp. & & $\mathbf{x}$ & & $\mathbf{x}$ & $\mathbf{x}$ \\
\hline \multicolumn{6}{|l|}{ Crustacea } \\
\hline Microcharon sp. & & & & & $\mathbf{x}$ \\
\hline \multicolumn{6}{|l|}{ Monolistra racovitzai spp. Strouhal, } \\
\hline 1928 & & & & $\mathbf{x}$ & $\mathbf{x}$ \\
\hline Monolistra velkovrhi Sket, 1960 & & & $\mathbf{x}$ & & $\mathbf{x}$ \\
\hline Niphargus sp. & & & & $\mathbf{x}$ & $\mathbf{x}$ \\
\hline \multicolumn{6}{|l|}{ Niphargus sp. } \\
\hline \multicolumn{6}{|l|}{ Niphargus sp. } \\
\hline \multicolumn{6}{|l|}{ Niphargus subtypicus Sket, 1960} \\
\hline \multicolumn{6}{|l|}{ Proasellus parvulus (Sket, 1960) } \\
\hline Troglocaris sp. (larva) & & & & $\mathbf{x}$ & $\mathbf{x}$ \\
\hline Troglodiaptomus sketi Petkovski, 1978 & & $\mathbf{x}$ & & & \\
\hline \multicolumn{6}{|l|}{ Surface aquatic species } \\
\hline Cyclopoida & & & $\mathbf{x}$ & $\mathbf{x}$ & $\mathbf{x}$ \\
\hline Cyclostomata (larva) & & & & $\mathbf{x}$ & \\
\hline Gammarus fossarum Koch, 1836 & & & & $\mathbf{x}$ & \\
\hline \multicolumn{6}{|l|}{ Hydra sp. } \\
\hline Pisces (larvae) & & & & $\mathbf{x}$ & \\
\hline \multicolumn{6}{|l|}{ Terrestrial species } \\
\hline Chilopoda & & & $\mathbf{x}$ & $\mathbf{x}$ & \\
\hline Diplopoda & & & $\mathbf{x}$ & $\mathbf{x}$ & \\
\hline Diplura & & & & $\mathbf{x}$ & \\
\hline
\end{tabular}

3.3.3 Reproduction. - The finding at Jelševnik of an embryonic larva of stage 21 (still swollen by vitellus and probably not able to move around in an organised way) speaks in favour of oviparity in P. a. parkelj, as is likely to be the case in P. a. anguinus (Briegleb, 1962; Sket \& Velkovrh, 1978).

\section{Discussion}

\subsection{Taxonomic status of the black Proteus}

The black morph of Proteus can be distinguished from the white morph by: (1) synthesis of pigment in the absence of light, (2) fully developed eyes, (3) the shape of some cranial bones and the number of teeth, (4) a different head shape stemming from a well-developed head musculature, (5) a high number of trunk vertebrae and its associated long trunk, (6) short relative length of the tail, and (7) short relative length of the legs.

On the basis of these evidently constant differences the black and white morph deserve attribution to separate taxa. On many occasions differences of similar magnitude have led to the recognition of separate species or even genera. Examples include the characinid fish Astyanax fasciatus Cuvier, 1819 and its cave relative Anoptichthys jordani Hubbs \& Innes, 1936, that have recently been shown to be completely interfertile (Culver, 1982).

Unfortunately, in Proteus crossing experiments pose the greatest of technical difficulties and to test for interfertility will be almost impossible. So far both morphs have in nature only been documented in allopatric conditions. The observed genetic distance of $D_{\mathrm{Nei}}=0.24$ between the black Proteus and the white population from Sticna is similar to the distances found for the various forms within the Triturus cristatus superspecies, that to a large extent are genetically isolated from one another (Wallis \& Arntzen, 1989; Arntzen, in prep.).

According to the results of the allozyme study, the black morph is phylogenetically closer to the populations of Stična than to the population of Planina. In view of them being morphologically similar, the large genetic distance between Planina and Sticna populations is remarkable. If a study of populations that are geographically intermediate would fail to indicate a pattern of clinal variation, we would identify the populations of Stična as a species separate from $P$. anguinus. Nomenclatorial priority would go to Proteus zoisii (Fitzinger, 1850) of which Rupnica is the type locality. The morphologically indistinguishable and biochemically similar population from Vir should be attributed to the 

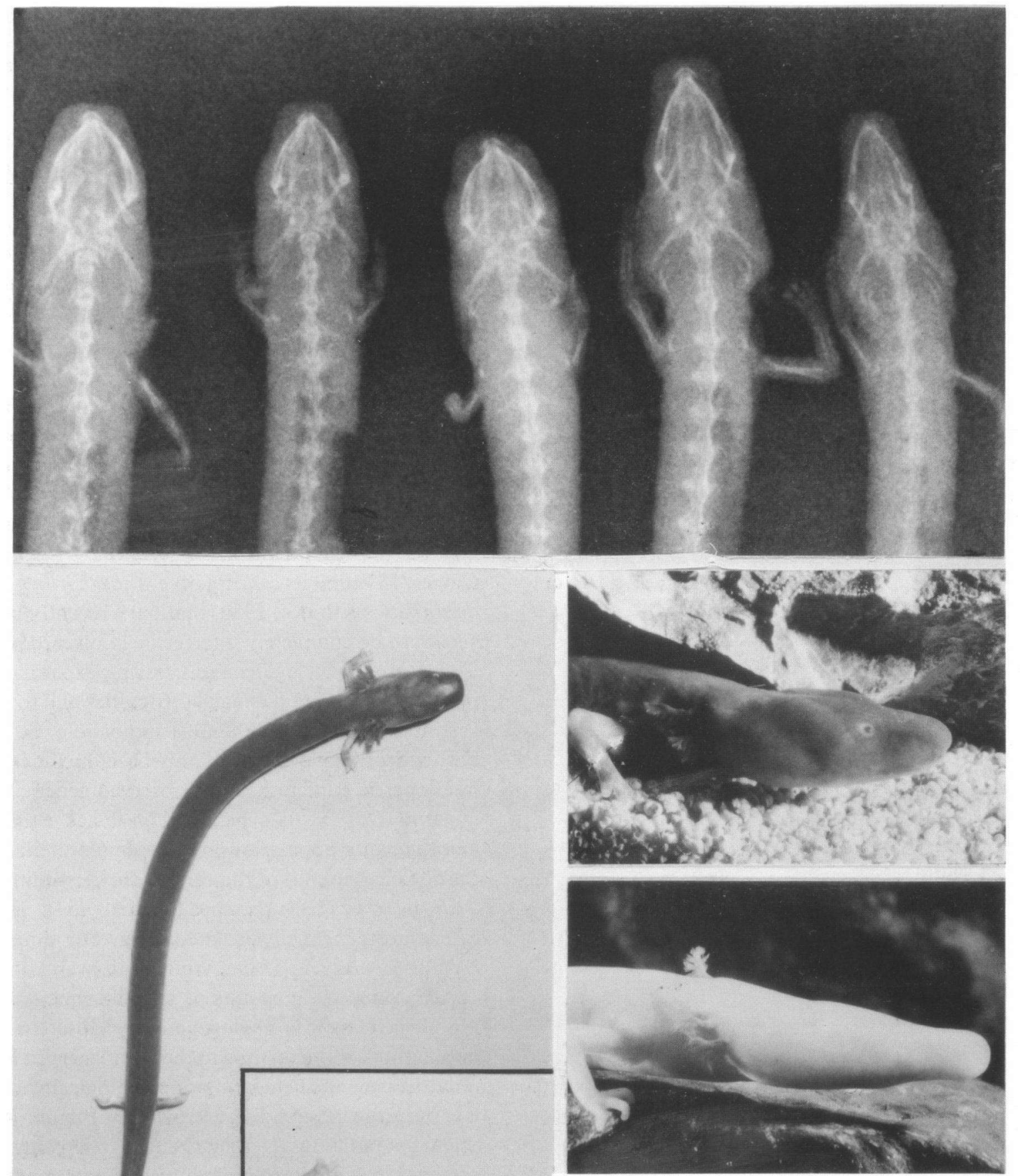

Plate I. Top: X-ray photographs of $P$. a. parkelj and $P$. a. anguinus, from left to the right specimen numbers are J9, J8, J3, R1, and P5 (see Table II; photo: V. Tabor); left: live specimen of Proteus anguinus parkelj from Jelševnik in dorsal view, the insert shows the head in detail (photo: B. Sket); middle and bottom: anterior parts of $P$. a. parkelj and $P$. a. anguinus in lateral view (photos: A. Hodalič). 
same taxon (although previously it has been given a name of its own: Hypochthon schreibersii Fitzinger, 1850). If such a revision would be followed, the black morph would be attributed to $P$. zoisii as the subspecies $P$. $z$. parkelj. An osteological synapomorphy in the shape of a less equally segmented tail skeleton, such as found in the populations of Jelševnik and Vir (Fig. 6) might speak in favour of a taxonomic separation of the Planina population.

Recognition of two species of Proteus would raise the question whether or not the black morph would also deserve specific status. A genetic distance of $D_{\mathrm{Nei}}=0.24$ is not a priori incompatible with this view, while the morphological distinctiveness of the black morph speaks in its favour. The finding of genetically isolated sympatric black and white Proteus would help proving the point. In the absence of firm phylogenetic, ecological, and genetic data we as yet refute such taxonomic revisions in favour of conservatively recognising a single species rather than two or three species.

\subsection{Biogeographic and evolutionary history}

At present the regions of Planina, Stična, and Jelševnik drain towards the Sava and the Danube, but little doubt exists about the mutual isolation of their hypogean habitats (cf. Gams, 1965; Novak, 1990). The genetic data suggest that the western Proteus population from Planina has become isolated from the eastern Stična and Jelševnik populations earlier than the Stična and Jelševnik populations with regard to each other.

In amphibians the "molecular clock" has been calibrated as one unit of $D_{\mathrm{Nei}}$ reflecting $14 \mathrm{My}$. of lineage separation (Maxson \& Maxson, 1979). For the genus of aquatic salamanders Triturus it has been shown that this calibration fits with independently derived estimates of speciation times; on that basis a consistent biogeographic scenario could be put forward, which corresponds to the vicariance biogeography of other amphibian and non-amphibian taxa (Oosterbroek \& Arntzen, 1992). Applying this calibration to Proteus, while keeping the standard error to the estimate of genetic distance in mind, this would mean that the first documented separation of Proteus lineages took place some 9-5 My. ago, which corresponds to the upper Miocene or lower Pliocene. Following the same line of argumentation, the Stična and Jelševnik populations show lineage independence for 4.5-1.1 My. This coincides with the upper Pliocene to the lower Pleistocene.

It is generally agreed that the prekarstic MiocenePliocene surface streams of the Stična region and the Bela Krajina flew in approximately the same direction as they do today. There is, however, some controversy concerning the situation around Postojna (cf. Melik, 1951, 1952; Jenko, 1959). Some zoogeographic data, including the distribution of the isopod crustaceans Asellus aquaticus cavernicolus Racovitza, 1925 and Proasellus istrianus (Stammer, 1932) speak in favour of an ancient hydrographic connection between the Postojna region and the Gulf of Trieste (Sket, in prep.). At the end of the Miocene, southern Slovenia became tectonically active which resulted in the presence of large depressions with lakes (Prelogović et al., 1975) and in changes in the direction of the flow of rivers. We suggest that Proteus may have formed a series of taxa in surface rivers and lakes before the Pliocene, with morphological differentiation developing between them. Proteus appears to be another example of a cave species in which the distribution and phylogenetic relationships relate to the prekarstic paleohydrology, rather than to the present-day situation (cf. Sket, 1970, 1986; Sket \& Bole, 1982).

With the karstification, a new, hypogean habitat became available to Proteus. Governed by environmental conditions, the phenotypical differentiation may locally have become obscured through evolutionary convergent, troglomorphic adaptations. Why the black Proteus has not undergone such adaptive change remains an open question. The retention of non-troglomorphic traits may be associated to weak selection (cf. Sket, 1985) or to a relatively recent colonization of the hypogean habitat.

The Pleistocene has seen several glaciations but no evidence is available to document that these extended onto Slovene territory before $1 \mathrm{My}$. ago (cf. Bowen et al., 1986; V. Pohar, pers. comm.). 
Intensive karstification, moving surface streams underground, caused complex hydrographical changes. With the karstification proceeding, the Proteus populations from Sticna and Jelševnik may have become isolated from one another, but not necessarily in caves. In a time span similar to their isolation or less, some stocks within the genus Triturus developed into clearly distinct species (Rafinski \& Arntzen, 1987; Oosterbroek \& Arntzen, 1992).

\subsection{Character evolution}

Within Proteus, the presence of externally differentiated eyes seems unique to $P$. a. parkelj. Kammerer (1912), on the basis of experiments that so far have not successfully been repeated (Durand, 1973), claimed that under the influence of light, blind Proteus may develop eyes and pigmentation. Occasional observations on captive Proteus do suggest that the ability of pigment synthesis is retained indeed (Ehrenberg, 1867 in: Knauer, 1878), but thoroughly conducted experiments have not been carried out in Proteus, nor in any other cave amphibian. The newly developed pigmentation may cover the whole body or only part of it (Aljancič et al., 1986), while retaining a white triangle on the snout (Ehrenberg, 1867 in: Knauer, 1878) - perhaps not unlike that found in $P$. a. parkelj.

The Jelševnik population of Proteus is pigmented although specimens are normally not exposed to daylight. As in Proteus, the atavism of melanin synthesis is found in some cavernicolous fish while others seem to have completely lost the ability (see e.g. Vandel, 1965: 408). The pigmentation of $P$. $a$. parkelj along with the well-developed eyes, are considered to be plesiomorphic traits. Since the duck-bill shape of the $P$. a. anguinus head is an attribute typical of troglobiont vertebrates (cf. Vandel, 1965; Cooper \& Kühne, 1974), occurring in fishes as well as in plethodontid amphibians, it can be regarded apomorphic compared to the plesiomorphic shape of $P$. a. parkelj. The change in head shape seems to be associated with a narrowing of the neurocranial bones and the mandibular arch and a weakening of the major head musculature.
The elongation of the snout may be associated with a slight elongation of the mandibular bones and an increase in the number of teeth they carry. The diminution of the eye with the small eye bulb freely below the skin has not affected the skull as in Astyanax fasciatus (Breder, 1944; cited by Culver, 1982).

\subsection{Distribution, threats, and legal protection}

Up to the present, Jelševnik and Doblicica are the only localities where $P$. $a$. parkelj has been found with certainty. No reliable data exist on the finding of Proteus in the main spring of Jelsevnik. A report on the finding of a black Proteus near Mala Lahinja (A. Hudoklin, pers. comm.), located $7 \mathrm{~km}$ to the southeast of Dobličica and within the region of low karst, has not been documented. No Proteus have been reported from springs south of Dobličica (F. Velkovrh, pers. comm.) or in any of the few active caves south of Crnomelj. Unfortunately, all over the Poljanska Gora the speleobiological sampling conditions are unfavourable.

Black Proteus in populations of whites? The only mention of the natural occurrence of "black" specimens by Graf (1882) unfortunately is not accompanied by any morphological data. The particular karst spring in Slovenska Vas (formerly Windischdorf) near Kočevje (Gottschee) in southeastern Slovenia has now been adopted for the town's water supply. In recent years only white specimens have been obtained from here.

White Proteus in populations of blacks? Local inhabitants reported on the finding of white Proteus in a locality between Jelševnik and Doblicica. Unfortunately no voucher specimens have become available and the reports will have to be confirmed. A voucher specimen does exist for a locality at $12 \mathrm{~km}$ to the northeast of Jelševnik (Klepec, 1981; cf. Fig. 1).

If the hypogean waters of the high karst of the Poljanska Gora are its defined habitat, the existence of $\boldsymbol{P}$. a. parkelj may be limited to water channels in the hydrographical background of both springs that cover an area of approximately $55 \mathrm{~km}^{2}$ (cf. Habič et al., 1990). As has been suggested by 
P. Habic (pers. comm.), the occurrence of $P$. $\boldsymbol{a}$. parkelj may in fact be restricted to the shallow karst of the Bela Krajina while the deep karst of the surrounding mountains is inhabited by the white taxon. The available data do not contradict this hypothesis. Indeed, the hypothesis is in line with (unconfirmed) data about the sporadic occurrence of white Proteus in Jelševnik and black Proteus in the springs of Lahinja. Because Proteus are difficult to find, their perceived absence in any area does not provide a powerful argument.

The water from the $\mathrm{Na}$ Trati boiling holes at Jelševnik is polluted. The contamination can be attributed to the dump of a smelting plant in a karst doline uphill the Poljanska Gora, less than a kilometre away. The fine grained and skin damaging sandy debris dumped in the doline is rich in phenols. It has been demonstrated that (white) Proteus in captivity did not survive a ten day period when kept in close contact with these sands ( $T$. Valentinčic, pers. comm.). We consider the pollution a serious threat to the survival of $P$. a. parkelj. The boiling holes of Jamnice are hydrologically similar but pollution has not been noticed there.

Since its habitat is not directly accessible to man, a population estimate cannot easily be performed. As it appears to be a rare taxon with a small distribution area, $P$. a. parkelj has been placed on the Slovenian Red List of endangered animal species (Sket, 1992). It is under strict protection of the Slovenian law as a member of the category "permanently cavernicolous animals", as well as in its own right as a subspecies of $P$. anguinus. We discourage collecting for any purpose. The most recent "Ordinance on protection of rare or endangered animal species and their developmental stages" (Brelih \& Gregori, 1980) has become operational in 1976 and a new act updating the old one is in preparation.

\section{Acknowledgements}

P. Habič, A. Mihevc, M. Zlokolica (Postojna), F. Velkovrh (Ljubljana), and A. Hudoklin (Novo Mesto) provided valuable information while M. Aljancic (Kranj), J.-P. Durand (Paris), and H. Hagn (München) drew our attention to some literature that otherwise would have gone unnoticed. F. Tiedeman (Vienna) provided specimens for biometrical analysis and Mrs. N.
Kranjec (Koper) performed biometrical studies that we used for comparison. Mrs. V. Tabor and J. Subelj (Ljubljana) helped us out with the X-ray photography and A. Brancelj (Ljubljana) identified Copepoda. A. Hodalix (Lausanne) made colour slides that we reproduce and R. Griffiths (Canterbury) and A. Zuiderwijk (Amsterdam) provided some of the outgroup material. M. García-París (Madrid) critically read the manuscript. Special thanks are due to Silvo Medic and his family, inhabitants of the hamlet of Jelševnik, for promptly informing us about the local hydrological conditions and for conscientiously collecting animals. Part of this study was funded by the Slovenian Ministry for Science and Technology.

\section{References}

Aljančix, M., P. Habič \& A. Mihevc, 1986. Čnni moðeril iz Bele Krajine [The black Proteus from the White Carniola]. Naše Jame, 28: 39-44.

Aljančič, M. \& B. Sket, 1964. Primer akcidentaine superregeneracije pri močerilu (Proteus anguinus Laur.) [Cas de superrégéneration accidentelle chez le Protée Proteus anguinus Laur.] Biol. Vest., 12: 109-113.

Arntzen, J.W. \& G.P. Wallis, in press. The 'Wolterstorff Index' and its value to the taxonomy of the Crested Newt superspecies. Abh. Ber. Mus. Naturk. Vorgesch. Magdeburg, Special Issue Wolterstorff Memorial Symposium.

Ayala, F.J., J.R. Powell, M.L. Tracey, C.A. Mourão \& PérezSalas, 1972. Enzyme variability in the Drosophila willistoni group, IV. Genic variation in natural populations of Drosophila willistoni. Genetics, 70: 113-139.

Behler, J.L. \& F. Wayne King, 1979. The Audubon Society field guide to North American reptiles and amphibians: 1-743 (Alfred A. Knopf, New York).

Bowen, D.Q., G.M. Richmond, D.S. Fullerton, V. Sibrava, R.J. Fulton \& A.A. Velichko, 1986. Correlation of Quaternary glaciations in the northern hemisphere. In: V. Sibrava, D.Q. Bowen \& G.M. Richmond (eds.), Quaternary glaciations in the northern hemisphere: 509-510 (Pergamon Press, Oxford).

Brelih, S. \& J. Gregori, 1980. Redke in ogrožene živalske vrste v Sloveniji [Rare and endangered animal species in Slovenia]: 1-263 (Prir. Muz. Slov., Ljubljana).

Briegleb, W., 1962. Zur Biologie und Oekologie des Grottenolms (Proteus anguinus Laur. 1768). Z. Morph. Ökol. Tiere, 51: 271-334.

Bulog, B., 1991. Preliminary study of the sensory organs of the Proteus sp. - black specimen (Urodela, Amphibia). The eye. Abstracts Ordinary General Meeting Societas Europaea Herpetologica, 6: 20.

Bulog, B., 1992. Ultrastructural analysis of the retina of Proteus sp. - dark pigmented specimens (Urodela, Amphibia). Electron Microscopy EUREM '92, 3: 659-660.

Conant, R., 1975. A field guide to reptiles and amphibians of eastern and central North America (2nd ed.): i-xviii, 1-429 (Houghton Mifflin, Boston). 
Cooper, J.E. \& R.A. Kühne, 1974. Speoplatyrhinus poulsoni, a new genus and species of subterranean fish from Alabama. Copeia, 1974: 186-193.

Culver, D.C., 1982. Cave life: evolution and ecology: i-viii, 1-189 (Harvard Univ. Press, Cambridge Mass. \& London).

Dolivo-Dobrovolsky, V., 1926. Lobanja človeške ribice (Proteus anguinus Laurenti) [Der Schädel des Grottenolmes (Proteus anguinus Laurenti)]. Rad JAZU, 232: 190-210, pls. 1-7.

Duellman, W.E. \& L. Trueb, 1986. Biology of amphibians: ixvii, 1-670 (McGraw-Hill, New York etc.).

Durand, J.-P., 1973. Développement et involution oculaire de Proteus anguinus Laurenti urodèle cavernicole. Annls. Spéléol., 28: 193-208.

Durand, J.-P. \& B. Delay, 1981. Influence of temperature on the development of Proteus anguinus (Caudata: Proteidae) and relation with its habitat in the subterranean world. J. thermal Biol., 6: 53-57.

Estes, R. \& I. Darevsky, 1977. Fossil amphibians from the Miocene of the North Caucasus, U.S.S.R. J. paleontol. Soc. India, 20 ("1975"): 164-169.

Estes, R.D. \& H.H. Schleich, in press. New material of Mioproteus caucasicus Estes and Darevsky from south German localities (Amphibia: Caudata: Proteidae). Cour. Forsch.Inst. Senckenberg.

Farris, J.S., 1972. Estimating phylogenetic trees from distance matrices. Am. Nat., 106: 645-668.

Fitzinger, L., 1850. Über den Proteus anguinus der Autoren. Sitzungsber. Akad. Wiss. Wien math.-naturw. Cl., 2: 291303.

Gams, I., 1965. Aperçu sur l'hydrologie du Karst slovene et sur ses communications souterraines. Naše Jame, 7: 51-60.

Graf, E., 1882. Die Grottenwelt von Gottschee. Mitth. Sect. Hoehlenk. oesterr. Touriste-Club, 1: 1-10.

Habix, P., 1991. Geomorphological classification of NW Dinaric karst. Acta carsol., 20: 133-165.

Habix, P., J. Kogovక̌ek, M. Bricelj \& M. Zupan, 1990. Izviri Dobličice in njihovo sirše kraško zaledje [Dobličica springs and their wider karst background]. Acta carsol., 19: 5-100.

Harris, H. \& D.A. Hopkinson, 1976. Handbook of enzyme electrophoresis in human genetics (without consecutive pagination; North-Holland Publ. Co., Amsterdam).

Herre, W., 1935. Die Schwanzlurche der mitteleocaenen (oberlutetischen) Braunkohle des Geiseltales und die Phylogenie der Urodelen unter Einschluss der fossilen Formen. Zoologica, 33 (87): 1-85.

Hodalix, A., 1993. Proteus: A la recherche du mystérieux “poisson-humain". Animan, 42: 30-49.

Humason, G.L., 1967. Animal tissue techniques (2nd ed.): 1569 (W.H. Freeman and Co., San Francisco).

Istenič, L., 1987. O najdbi črne človeške ribice [On the finding of a black proteus]. Proteus, 49: 243-244.

Istenix, L. \& B. Bulog, 1986. Crni moðeril še pod drobnogledom [The black proteus under the microscope]. Delo, 25. Nov. 1986: 8.

Jenko, F., 1959. Hidrologija in vodno gospodarstvo krasa [Hydrology and water management in karst]: 1-237 (Državna založba Slovenije, Ljubljana).

Kammerer, P., 1912. Experimente über Fortpflanzung, Farbe, Augen und Körperreduktion bei Proteus anguinus Laur. Archiv Entwicklungsm., 33: 349-461, pls. I-IV.

Klepec, S., 1981. Cloveška ribica tudi v Beli krajini [Proteus also in Bela Krajina]. 3. dolenjski jamarski Tabor, Kostanjevica: 37-39.

Knauer, F., 1878. Naturgeschichte der Lurche (Amphibiologie). Eine umfassendere Darlegung unserer Kenntnisse von dem anatomischen Bau, der Entwicklung und systematischen Eintheilung der Amphibien sowie eine eingehende Schilderung des Lebens dieser Thiere: $i-x x, 1-340,2$ tables, 4 maps (A. Pichler's Witwe \& Sohn, Wien).

Kranjec, N., 1981. Razširjenost in variabilnost močerila (Proteus anguinus Laurenti) [Distribution and variability of Proteus anguinus]. Graduation thesis, Ljubljana: 1-70.

Lanyon, S.M., 1985. Detecting internal inconsistencies in distance data. Syst. Zool., 34: 397-403.

Maurer, H.R., 1971. Disc electrophoresis and related techniques of polyacrylamide gel electrophoresis (2nd ed.): i-xvi, 1-222 (De Gruyter, New York).

Maxson, L.R. \& R.D. Maxson, 1979. Comparative albumin and biochemical evolution in plethodontid salamanders. Evolution, 33: 1057-1062.

Melik, A., 1951. Pliocenska Pivka [The Pliocene Pivka River]. Geogr. Vestn., Ljubljana, 23: 17-39.

Melik, A., 1952. Zasnova Ljubljanixinega porečja [Origins of the Ljubljanica river basin]. Geogr. Zborn., Ljubljana, 1: 531.

Melik, A., 1958. Jugoslavija: 1-675 (Tiskovna zadruga, Ljubljana).

Mertens, R. \& L. Müller, 1940. Die Amphibien und Reptilien Europas. Abh. senckenberg. naturf. Ges., 451: 1-56.

Nei, M., 1972. Genetic distance between populations. Am. Nat., 106: 283-292.

Nei, M., 1987. Molecular evolutionary genetics: i-x, 1-512 (Columbia U.P., New York).

Novak, D., 1990. Novejša sledenja kraških voda v Sloveniji po letu 1965 [Recent tracing of karstic waters in Slovenia]. Geologija (Ljubljana), 33: 461-478.

Oosterbroek, P. \& J.W. Arntzen, 1992. Area-cladograms of circum-Mediterranean taxa in relation to Mediterranean palaeogeography. J. Biogeogr., 19: 3-20.

Pehani, H. \& A. Seliškar, 1941. O dozdevni metamorfozi heteroplastičnih transplantatov kože neoteničnih amfibij [On the supposed metamorphosis of heteroplastic skin grafts of neotenic amphibians]. Zbornik prir. Društ., 2: 119-124.

Peters, N., G. Peters, J. Parzefall \& H. Wilkens, 1973. Über degenerative und konstruktive Merkmale bei einer phylogenetisch jungen Höhlenform von Poecilia sphenops (Pisces, Poeciliidae). Int. Revue ges. Hydrobiol., 58: 417-436.

Poulik, M.D., 1957. Starch gel electrophoresis in a discontinuous system of buffers. Nature, 180: 1477-1479.

Prelogović, E., M. Arsovski, V. Kranjec, V. Radulović, B. Sikošek \& S. Soklič, 1975. Paleogeografska evolucija teritorije Jugoslavije od tercijera do danas [Palaeogeographic 
development of the Yugoslav territory since the Tertiary.] Acta seismologica jugoslavica, 2-3: 7-11, maps.

Rafinski, J. \&. J.W. Arntzen, 1987. Biochemical systematics of the Old World newts, genus Triturus: allozyme data. Herpetologica, 43: 446-457.

Rogers, J.S., 1972. Measures of genetic similarity and genetic distance. Stud. Genet. VII, Univ. Texas Publ., 7213: 145154.

Romer, A.S. \& T.S. Parsons, 1977. The vertebrate body (5th ed.): i-viii, 1-624 (Saunders, Philadelphia etc.).

Schreiber, E., 1912. Herpetologia europaea. Eine systematische Bearbeitung der Amphibien und Reptilien welche bisher in Europa aufgefunden sind (2nd. ed.): i-x, 1-960 (Gustav Fischer, Jena).

Shaw, C.R. \& R. Prasad, 1970. Starch gel electrophoresis of enzymes - a compilation of recipes. Biochem. Genet., 4: 297320.

Sket, B., 1970. Über Struktur und Herkunft der unterirdischen Fauna Jugoslawiens. Biol. Vestn., 18: 69-78.

Sket, B., 1983. Je Marifugia res ubežnik iz morja? [Is Marifugia really a fugitive from the sea?] Proteus, 46: 102-104.

Sket, B., 1985. Why all cave animals do not look alike - a discussion on adaptive value of reduction processes. NSS Bull., National Speleological Society, 47: 78-85.

Sket, B., 1986. Evaluation of some taxonomically, zoogeographically, or ecologically interesting finds in the hypogean waters of Yugoslavia (in the last decades). 9. Congr. int. Espeleol., Comun., 2: 126-128.

Sket, B., 1992. Rdeči seznam ogroženih vrst dvoživk (Amphibia) v Sloveniji [The Red List of endangered Amphibia in Slovenia]. Varstvo narave, 17: 45-49.

Sket, B. \& J. Bole, 1982. Organisms as indicators of hypogean water connections (summary). Naš Krš. (Sarajevo), 6: 115117.

Sket, B. \& F. Velkovrh, 1978. The discovery of Proteus-eggs (Proteus anguinus Laurenti, Amphibia) in seminatural conditions. Int. J. Speleol., 10: 205-209.

Sneath, P.H.A. \& R.R. Sokal, 1973. Numerical taxonomy. The principles and practice of numerical classification: $i-x v$, 1-573 (W.H. Freeman, San Francisco).

Swofford, D.L. \& R.B. Selander, 1981. BIOSYS-1: A FORTRAN program for the comprehensive analysis of electrophoretic data in population genetics and systematics. J. Hered., 72: 281-283.

Valvasor, J.W., 1689. Die Ehre des Herzogthums Crain: 1-696 (W.M. Endtner, Nürnberg).

Vandel, A., 1965. Biospeleology. The biology of cavernicolous animals: i-xxiv, 1-524 (Pergamon Press, Oxford).

Vandel, A. \& M. Bouillon, 1959. Le Protée et son intérêt biologique. Annls. Spéléol., 14: 111-127.

Vandel, A., J. Durand \& M. Bouillon, 1966. Contribution à l'étude du développement de Proteus anguinus Laurenti (Batraciens, Urodèles). Annls. Spéléol., 21: 609-519.

Wallis, G.P. \& J.W. Arntzen, 1989. Mitochondrial-DNA variation in the crested newt superspecies: limited cytoplasmic gene flow among species. Evolution, 43: 88-104.

Wilkinson, L., 1989. SYSTAT: The system for statistics: manual for computer programme (SYSTAT Inc., Evanston, IL.).

Wolterstorff, W., 1923. Übersicht der Unterarten und Formen des Triton cristatus Laur. Blätter Aquar. Terrarienk. Stuttgart, 34: 120-126.

Received: 29 June 1993

Revised: 17 November 1993 